\title{
How Well Do Institutional Theories Explain Firms' Perceptions of Property Rights?
}

\author{
Meghana Ayyagari \\ Asli Demirgüç-Kunt \\ Vojislav Maksimovic*
}

June 2005

\begin{abstract}
We examine how well several institutional and firm-level factors and their interactions explain firms' perceptions of property rights protection. Our sample includes private and public firms which vary in size from very small to large in 62 countries. Together, the institutional theories we investigate account for approximately $70 \%$ of the country-level variation, indicating that the literature is addressing first-order factors. Firm-level characteristics, such as legal organization and ownership structure, are comparable to institutional factors in explaining variation in property rights protection. A country's legal origin and formalism index predict property rights variation better than its openness to international trade, its religion, its ethnic diversity, natural endowments or its political system. However, these results are driven by the inclusion of former Socialist economies in the sample. When we exclude the former Socialist economies, legal origin explains considerably less than openness to trade and endowments. Examining a broader set of variables for robustness, we again find that when we exclude former Socialist countries, legal origin explains comparatively little of the variation in perceptions of judicial efficiency, corruption, taxes and regulation, street crime and financing.
\end{abstract}

Keywords: Law, Property Rights, Variance Decomposition

\section{JEL Classification: D23, K4, C5}

\footnotetext{
*Ayyagari: School of Business, George Washington University; Demirgüç-Kunt: World Bank; Maksimovic: Robert H. Smith School of Business at the University of Maryland. We would like to thank Thorsten Beck, Murray Frank, Phillip Keefer, Leora Klapper, Gordon Phillips, Colm Kearney and seminar participants at Rutgers and George Washington University for their suggestions and comments. This paper's findings, interpretations, and conclusions are entirely those of the authors and do not necessarily represent the views of the World Bank, its Executive Directors, or the countries they represent.
} 


\section{Introduction}

In modern corporate finance, it is taken as axiomatic that the firm is a "nexus of contracts' (Jensen and Meckling (1976)). Many of the predictions of corporate theory depend at some level on how well protected property rights assigned by these contracts really are. People may be less willing to invest and more willing to engage in opportunistic behavior if property rights are insecure. Several serious theories have recently been advanced to explain the underlying determinants of property rights across countries. The seminal Law and Finance theory (La Porta, Lopez-de-Silanes, Shleifer and Vishny (henceforth LLSV) (1998)) stressed the importance of legal traditions. Other influential work has taken a broader view, stressing Culture and Ethnic diversity (Stulz and Williamson (2003), Easterly and Levine (1997)), Endowments (Acemoglu, Johnson, and Robinson (2001)), Openness to trade (Rajan and Zingales (2003)), and Political power (Acemoglu (2003)). ${ }^{1}$

While all seem to contain elements of truth, it is important to distinguish which theories are relatively more important. In this paper we study the perceptions of business people in different countries regarding how well protected their property rights really are in practice. By matching these perceptions with country level and firm level factors we are able to assess the relative importance of each of these theories. Using a variance decomposition approach, we examine differences between countries as well as differences between firms.

We find that, in our full sample, the law and finance approach appears to do well in explaining firms' perceptions of property rights. However, that appearance is critically dependent on how we treat the former Socialist countries. If we pool them with the rest, then legal origin alone explains about a quarter of the variation in firms' perception of

\footnotetext{
${ }^{1}$ Substantial progress has also been made in explaining the relation between the origins and efficiency of legal systems and the characteristics and policies of firms. Examples include studies of corporate valuations (LLSV, 2002; Doidge, Karolyi, and Stulz, 2004), ownership concentration (LLSV 1999b; Morck, Yeung, and Wolfenzon, 2004; Himmelberg, Hubbard, and Love, 2002; Ayyagari 2004), dividend policies (LLSV, 2000b), cross- firm and cross- industry capital allocation (Wurgler, 2000; Beck and Levine, 2002; Claessens and Laeven, 2003), the informational efficiency of stock prices (Morck, Yeung, and Yu, 2000), financial fragility (Johnson, et al., 2000), and firm growth and financing (Demirguc-Kunt and Maksimovic 1998, 1999; Beck, Demirguc-Kunt and Maksimovic 2005)).
} 
property rights protection that is attributable to country-level effects. Theories that place emphasis on a country's natural endowments (Acemoglu, Johnson, and Robinson (2001)) and the views that stress the importance of openness to trade and political variables (Rajan and Zingales (2003), Acemoglu (2003)), while not as strong, also do well.

If we argue that the former Socialist countries need to be handled separately, then the explanatory power of legal origin decreases dramatically. Legal Origin explains only $7 \%$ of the variation in property rights protection at the country level. A country's latitude, and openness to trade, entered individually, explain $18 \%$ and $20 \%$ respectively, of the variation in the reduced sample, indicating support for the endowment and openness to trade views. Thus, we find that the strong performance of the Law and Finance view is not due to differences in the way common law and civil law treat investor rights, but due to the differences between countries with Socialist legal tradition and other countries. It may be noted that the original papers detailing the importance of legal origin for financial development, LLSV $(1998,1999)$ did not include any countries with Socialist legal tradition.

We further compare the institutional theories by looking at other variables that are related to property rights or that measure the firm's ability to enforce its rights against other parties. Specifically, we examine firms' perceptions of judicial efficiency, corruption, taxes and regulation, and street crime ${ }^{2}$. Judicial efficiency, corruption and taxes and regulation capture different aspects of the legal environment that affects firms' perceptions of property rights. We also examine two "outcome" variables that should be partially determined by property rights protection, the firm's access to financing and firm growth. Legal origin dummies again have the greatest explanatory power compared to other institutional theories but only in the case of judicial efficiency and taxes and regulation. Once we remove former Socialist countries from the sample, a country's latitude, openness to trade and political system do better than legal origin in explaining firms' perceptions of judicial efficiency, corruption, taxes and regulation, financing and street crime.

\footnotetext{
${ }^{2}$ Street crime, which is related to the general legal environment that firms face, has been identified as predicting firm growth in Ayyagari, Demirguc-Kunt and Maksimovic (2005).
} 
While the total overall variation in property rights explained at the country level by country dummies is low $(16.5 \%)$, the institutional variables when entered together account for nearly $77 \%$ of this country-level variation in the full sample and $73 \%$ of the country level variation in the sample without the former Socialist countries. Thus, the current debate about the country-level institutional factors that affect property rights is addressing important first order effects that significantly influence firms' perceptions of property rights. In fact, in a reduced sub-sample of 33 countries for which data on settler mortality is available, the various institutional theories together explain $99 \%$ of the variation at the country level.

We also find that firm-level characteristics have substantial explanatory power in our sample, in some cases even exceeding that of the individual country-level institutional factors. For the full sample, the ownership structure of the firm has the highest explanatory power, (nearly $43 \%$ that of legal origin, the country-level variable with the highest explanatory power in our full sample) followed by size and organizational form. ${ }^{3}$ However, once we drop the former Socialist countries, organizational form becomes the most important firm-level explanatory variable.

Conditional on knowing the country-level institutional variables, knowing a firm's characteristics adds relatively little to explaining its perception of property rights. This finding suggests that while the institutional factors affect the distribution of firms of different sizes, ownership structures and organizational forms in the economy, there is an equilibrating process whereby the population of businesses and, most likely, financial institutions adapt to country-level institutions. Hence, we find little evidence that different legal traditions or political systems treat different types of firms in their countries' existing population of firms differently. As a result, models that predict differences across firm types across countries should focus on specific institutional differences between jurisdictions rather than broad institutional differences, such as differences in legal origin or the level of political freedom.

Our analysis also uncovers a methodological issue that has not received adequate attention in the literature. The explanatory power of several institutional theories depends

\footnotetext{
${ }^{3}$ Firms can be organized as sole proprietorships, partnerships, cooperatives, private corporations or publicly traded corporations.
} 
on the proxies used to represent these theories. We identify several potentially significant scaling issues that occur if empirical tests do not pay attention to non-linearities arising out of the way the proxies are scaled. These scaling issues have the potential to overturn conclusions drawn from tests.

In comparing the different institutional theories, we exploit the World Business Environment Survey (WBES), a major cross-sectional survey conducted in developed and developing countries in 1999 and led by the World Bank. We use survey responses from 6012 firms in 62 countries to questions about property rights and firm characteristics. The survey contains data on small as well as large firms, and on private corporations and partnerships as well as publicly traded firms. ${ }^{4}$

In order to compare the different theories and to examine the relative influence of firm effects versus country effects, we use variance decomposition analysis. This methodology is well established in the corporate strategy literature in the context of decomposing profitability into corporate and industry effects (Schmalensee, 1985; Rumelt, 1991; McGahan and Porter, 1997, 2002; Khanna and Rivkin, 2001). ${ }^{5}$ The methodology allows us to focus directly on the general importance of these effects in explaining property rights without any assumptions on causality or structural analysis.

This paper is closely related to the recent work of Stulz, Karolyi and Doidge (2004) who investigate variation in the ratings of governance in large firms in a large sample of countries. They find that most of the variation in governance ratings across firms is explained by country characteristics rather than firm characteristics. They attribute this finding to the increased incentives of firms in better legal environments to adopt better governance structures.

Our paper differs from theirs in several respects. We test the explanatory power of alternative institutional theories. Our indicator of property rights measures the property rights of the firm as a whole, not of external investors. We examine a broad cross-section of firms that differ in size, ownership and organizational structure. Our sample includes sole proprietorships, partnerships as well as private and public corporations. In our more

\footnotetext{
${ }^{4}$ The WBES has been used by Love and Mylenko (2003), Djankov, La Porta, Lopez-de-Silanes, and Shleifer (2003), Beck, Demirguc-Kunt and Maksimovic (2005), Beck, Demirguc-Kunt and Levine (2005), Beck, Demirguc-Kunt, Laeven and Maksimovic (2005) among others.

${ }^{5}$ The original application of this methodology was in quantitative genetics to decompose variation in traits into a genetic component and an environment component (Jinks and Fulker (1970))
} 
diverse sample, country-level variation does not explain most of the variation in perceived property rights across firms - country dummies explain only $16.5 \%$ of the variation in property rights. However, country-level variation accounts for most of the variation that we can attribute to factors that we can identify. We provide measures of the relative importance of the country-level factors discussed in the literature. We also provide guidance on the relative importance of firm-level factors commonly used in the empirical literature.

In their paper on the determinants of financial system and stock market development, Beck, Demirguc-Kunt and Levine (2003) also discuss property rights protection. Our methodology and findings differ from theirs in several respects. First, while we use firm-level data on property rights protection, they use a country-level index compiled by the Heritage Foundation from several private and public sources. Second, while we consider each institutional theory separately, they focus on legal origin and settler mortality, usually in conjunction with geographical control variables that may themselves proxy for a country's endowment. Third, they do not address the issue of whether firm characteristics affect property rights protection. These factors perhaps explain why while we find a clear difference in the explanatory power of the legal origin and endowment views for property rights protection and for several related variables, their paper does not.

The rest of the paper is organized as follows: Section 2 discusses the various institutional determinants of property rights that we investigate in this paper. Section 3 presents the empirical methodology. Section 4 presents the data and the results of the variance decomposition analysis. We conclude with suggestions for future research in section 5 .

\section{Motivation}

LLSV (1998) argue that legal systems differ in how much they protect the rights of private investors vis-à-vis the state and minority shareholders. They argue that legal systems that evolved from common law traditions have tended to be supportive of private property rights. By contrast, civil law systems were established by states as acts of policy. 
They tend to be designed to state administration, are more predictable, and are less likely to favor individuals over the state or to tailor decisions in ways that safeguard individual claimants in specific instances. The LLSV theory focuses on the differences between five influential legal traditions: the British common law, the French civil law, the German civil law, the Scandinavian civil law and the Socialist law countries, all of which are examined in this paper.

Several studies have focused on the constraints placed on the judiciary by legal formalism. Acemoglu and Johnson (2003), Djankov et al. (2003) and Glaeser and Shleifer (2002) argue that strict adherence to formal procedures and rules may prevent courts from attaining fair outcomes. In principle, the extent of formalism may vary even across systems in the same tradition. Djankov et al. (2003) construct an index of legal formalism according to which formal procedures, such as the statutory justification and formal procedural steps are associated with judicial processes in a country. To the extent that reliance on bright-line rules and formal procedures is a material distinction between legal systems with the same tradition, this index gives an alternative, and potentially accurate, measure of a legal system's ability to protect property rights. However, under an alternative view (Acemoglu and Johnson (2003)), legal formalism measures the ease with which individual parties can contract, rather than the extent of their property rights protection. We refer to the effect of legal origin and legal formalism on property rights as the Law and Finance view.

Acemoglu, Johnson, and Robinson (2001) (henceforth AJR) argue that in many countries, especially former colonies, the legal system was not designed to protect property rights. Instead, its purpose was to facilitate the extraction of resources from the indigenous population. Thus, two systems with the same origin may in practice offer very different protections. AJR $(2001,2002)$ and Engerman and Sokoloff (1997) contend that European colonization offers a natural experiment to test this hypothesis. Europeans set up extractive systems in colonies which were not attractive for colonial settlement because of high settler mortality due to natural causes at the time of colonization or because the indigenous population was relatively large. In colonies where settlement was feasible the judicial systems were set up so as to protect the property rights of the settlers. This theory emphasizes the role of geography (latitude and natural endowments) and 
disease environment (which affected the settler mortality) in shaping property rights. We refer to this theory as the Endowment view. Since we have data on settler mortality for a smaller sample, we use latitude for our main results and present the results on settler mortality as a robustness table ${ }^{6}$.

Several researchers have argued that the effect of the legal system per se on property rights is limited, and that differences across countries in their enforcement depends on a broader range of cultural and social considerations. Thus, differences in culture, defined as a system of beliefs, and ethnic composition of the country can help explain the differences in investor protection. Stulz and Williamson (2003) and LLSV (1999) both use religion as a proxy for culture. Easterly and Levine (1997) show that ethnic diversity is also an important determinant of property rights and contracting institutions. For brevity, we term this the Culture and Ethnic Diversity view. Empirically, to capture these broader cultural and diversity effects we use a measure of ethnic fractionalization of the country from Easterly and Levine (1997) and four categories of classification for the religion variable: Catholic, Protestant, Muslim and Other Religions from LLSV (1999).

Acemoglu (2003) argues that the extent of property rights protection depends on the political regime in the country, whether it is a democratic society or an oligarchic society and also on the extent to which a certain group of people can dictate policy and institutional development. Rajan and Zingales (2003) also argue that poor property rights and financial underdevelopment might be the deliberate choice of established military / industrial elite in power ${ }^{7}$. We refer to this explanation of property rights as the Political view.

\footnotetext{
${ }^{6}$ Engerman and Sokoloff (1997) note that a second channel through which geographical endowments shape initial institutions is through openness and competition. They show that agriculture in southern North America and much of South America is conducive to large plantations. Thus, colonialists developed longlasting institutions to protect the few landowners against the many peasants. In contrast, northern North America's agriculture is conducive to small farms, so that more egalitarian institutions emerged. For the purposes of this paper, we focus on the AJR (2001) measure of settler mortality and latitude and not on agricultural endowments because the data on settler mortality and latitude is available for a broader crosssection of countries.

${ }^{7}$ North (1990) and Olson (1993) also argue that those in power shape policies and institutions to stay in power and enrich themselves.
} 
Rajan and Zingales (2003) argue that trade openness proxies for the extent to which certain established interests can restrict entry into their country's markets. According to this view, one would expect property rights to be better protected in countries that are more open to international trade. We term this the Openness view. Although the trade openness view is based on interest group theory and hence is closely related to the political view, we include it as a separate category since trade openness is partially endogenous and is more of a proxy variable than variables that explicitly measure the political system like democracy or autocracy.

Implicit in several of these theories is the prediction that certain classes of firms will have their property rights protected better than other types of firms in certain countries. Thus, for example, one would expect that in oligarchic societies, large incumbent firms would have a greater degree of property rights protection than smaller firms. By contrast, the legal origin view, and the culture and ethnic diversity view do not imply that the amount of property rights protection should depend more on firm size differences in certain countries than in other countries. By considering property rights protection at the firm level, we can provide evidence on the likely size of these interactive effects. Appendix A1 presents a comparison of the different theories and their implications for different types of firms.

In considering the interactions between country effects and firm effects, we examine several firm-level characteristics which are associated with different perceptions of property rights. Recent studies have shown that the effect of different financial and legal systems on firms varies according to the distribution of Firm Size. Differences in the effect of institutions across different types firms have also been found. Beck, Demirguc-Kunt and Maksimovic (2005) find that small firms grow more slowly in countries with weak financial institutions. Kumar, Rajan, and Zingales (2002) find that more efficient legal systems are associated with larger firm sizes across countries in Western Europe, an effect especially pronounced in industries characterized by low levels of capital intensity. In a study focused on Mexico, Laeven and Woodruff (2004) find that states with more effective legal institutions have larger firms.

Demirguc-Kunt, Love and Maksimovic (2004) show that incorporated firms grow comparatively faster in countries with strong financial and legal institutions than in 
countries with weak institutions. Beck, Demirguc-Kunt and Levine (2005) using the same WBES database, find that incorporated and family-owned firms face the highest financing obstacles. Thus, we also examine whether firms' perceptions of property rights are affected by their Organizational form and whether there exist interactions between organizational forms and the institutional variables.

There is also an extensive literature documenting a link between ownership structure and the institutional environment. LLSV (1997, 1998, 1999, 2000), Johnson, La Porta, Lopez-de-Silanes, and Shleifer (2000), and Burkart, Panunzi, and Shleifer (2003) show that legal protection of minority shareholders varies across countries, and this variation determines the level of ownership concentration, the existence of family firms worldwide, the patterns of separation between ownership and management, and the degree of expropriation by corporate insiders. Claessens and Fan (2002), Friedman, Johnson, and Mitton (2003) and Wolfenzon (1999) all argue that the propensity to tunnel and prop is higher for business groups, in particular if they are organized in pyramids. The recent spate of privatizations in Latin America and the transition economies has also brought the performance of state-owned enterprises versus other companies into focus. La Porta and Lopez-de-Silanes (1999) using the case of Mexican privatizations provide evidence that privately owned firms outperform state owned enterprises. Hence, we also investigate to what extent Ownership Structure influences firms' perceptions of how well property rights are protected.

Beck and Levine (2002) show that differences in legal and financial systems affect the availability of external finance and the growth of different industries in the manufacturing sector. We would expect these differences to matter as much or more when we look across different sectors. Hence, we also examine if belonging to a particular Industrial Sector impacts how firms perceive their property rights to be protected. 


\section{Methodology and Data}

Our analysis relies on the following reduced-form model of property rights protection. ${ }^{8}$ Let $\mathrm{y}_{\mathrm{ijk}}$ denote the perceived response of a firm $k$, belonging to a firm category $j$ and located in country $i$ :

$$
y_{i j k}=\mu+\alpha_{i}+\beta_{j}+\gamma_{i j}+\varepsilon_{i j k}
$$

where $\mu$ is the average response across all firms and countries, $\alpha_{i}$ are country effects $\left(i=1, \ldots, 1_{\alpha}\right), \beta_{j}$ are firm category effects $\left(j=1, \ldots 1_{\beta}\right), \gamma_{\mathrm{ij}}$ are country-firm interaction effects ( $1_{\gamma}$ distinct $i j$ combinations) and the $\varepsilon_{\mathrm{ijk}}$ are random disturbances. We look at four different categories at the firm level: firm size, ownership, legal organization and industry sector. At the country level, apart from the base regression using country dummies, we use ten other institutional variables to capture the various theories discussed in Section 2. Hence we are actually looking at 44 different models (four*eleven) that are different combinations of the firm and country factors. The premise in each estimation is that the model being estimated is the true one ${ }^{9}$.

The model takes the classification of firms into firm-categories and countries as given and is essentially descriptive. In particular, while it posits the existence of differences in responses across firms and countries, it offers no causal or structural explanation for these differences. Thus, for example, if we find that political institutions explain the variation better than legal origin, it leaves open the possibility that political institutions themselves are partially explained by legal origin. ${ }^{10}$

We analyze this model in two ways, a regression based, simultaneous ANOVA approach and the components-of-variance (COV) approach pioneered by Schmalensee (1985).

\footnotetext{
${ }^{8}$ In principle, institutional effects can be non-linear in complex ways, some of which we discuss below. However, the comparative finance literature on institutions relies on linear models, and such models are the starting point for our analysis.

${ }^{9}$ The inherent hierarchy in the variance decomposition methodology allows us to use only one variable at each level. This prevents us from using several institutional variables (or multiple firm effects) in the same regression.

${ }^{10}$ However, the ultimate "cause" of political institutions may not be of direct relevance for firm-level analysis since they would be taken as exogenous in such studies.
} 


\subsection{Simultaneous ANOVA Approach}

In our first approach to estimation, we analyze the variance in property rights protection using the standard assumptions of ordinary least squares. Equation (1) is a linear additive model that exhibits collinearity between the various sets of effects. To deal with this collinearity, the estimation approach reports the incremental explanatory power of each set of effects. We begin by estimating a restricted version of equation (1), where we exclude all effects other than the constant and the institutional variable. The $\mathrm{R}^{2}$ of this regression provides an estimate of the proportion of the variation in perceived property rights protection at the firm level, explained by the institutional variable alone. More precisely, it provides an upper bound for the amount that can be explained by that variable directly and by other variables that the institutional variable predicts. For example, assume that large firms report that their property rights are better protected than small firms and that the institutional variable under investigation is legal formalism. Then a regression of property rights protection on legal formalism will pick up the direct effects of legal formalism on firms' property rights. However, if firms in countries which are afflicted with high degrees of legal formalism are disproportionally small, then the regression will also pick up an indirect effect, arising from the association of legal formalism and the size composition of firms.

In each case, we next add the firm level characteristic and compute the $\mathrm{R}^{2}$ to obtain an estimate of the proportion of the variation in property rights explained by the institutional variable and the firm characteristic together. ${ }^{11}$ Finally, we add an interaction term, to provide for the possibility that the firm characteristics may affect property rights for some values of the institutional variable and not for other values.

Our measure of property rights protection has six discrete outcomes, and hence a linear model may not be entirely appropriate. However, as pointed out by Wooldridge (2003: p. 553), discreteness of the dependent variable does not in itself mean that linear models are inappropriate. Menard (1995) suggests that linear regression (ordinary least squares) is reasonable with ordinal dependent variables that have a large number of

\footnotetext{
${ }^{11}$ Note that the difference in $\mathrm{R}^{2}$ of the new regression and the restricted regression does not provide an estimate of the variation explained by the firm specific variable by itself, only the marginal increment of explanatory power that is gained by adding the firm specific variable. Thus, if legal formalism predicts firm size well, the marginal increase in $\mathrm{R}^{2}$ would be small, even if firm size and property protection are highly correlated.
} 
categories by treating the variables as though they were measured on an interval scale ${ }^{12}$. Since the choice of a non-linear form would be arbitrary we continue to use ordinary least squares for our estimation. We do perform robustness tests using a non-linear model specification and find our results to be unchanged. This is further discussed in section 4.4 of the paper.

\subsection{Components of Variance (COV)}

Variance decomposition allows one to gauge the importance of different effects without using a structural model and without any implicit assumptions on the direction of causality. The principal advantage over the ANOVA approach is that it treats all the explanatory variables symmetrically, independent of the order in which they are entered. $^{13}$

The components of variance approach assumes that each of the effects in (1), like the error term, are realizations of random processes with zero means and constant, but unknown variances, $\sigma_{\alpha}^{2}, \sigma_{\beta}^{2}, \sigma_{\gamma}^{2}$, and $\sigma_{\varepsilon}^{2}$. The random effects assumption stipulates that the effects in the data represent a random sample of the effects in the population ${ }^{14}$. Further, each of the effects is assumed to be independent. This allows us to decompose the total variance $\sigma_{y}^{2}$ of firm responses, following equation (1), into the following variance components:

$\sigma_{\mathrm{y}}^{2}=\sigma_{\alpha}^{2}+\sigma_{\beta}^{2}+\sigma_{\gamma}^{2}+\sigma_{\varepsilon}^{2}$.

where $\sigma_{\alpha}^{2}$ is the variance due to country effects, $\sigma_{\beta}^{2}$ is the variance due to firm effects, $\sigma_{\gamma}^{2}$ is the variance due to country-firm interaction effects and $\sigma_{\varepsilon}^{2}$ is the residual

\footnotetext{
${ }^{12}$ In the sociology and marketing literature, where use of ordinal variables from survey data is ubiquitous, it is common practice to treat ordinal variables as being continuous and to use ordinary least squares (OLS) estimation when the number of outcomes for the categorical dependent variable is greater than four. The assumption behind this is that when the number of cut-off points is greater than four, they may be considered to be approximately the same distance from each other.

${ }^{13}$ The components of variance approach was used by Schmalensee (1985) to explain the variability in profits across corporations and industries. This technique, which is originally described in Searle (1971), has been the genesis of a whole new dimension in the strategy literature in employing variance decomposition to examine if corporate effects matter more than industry effects in explaining firm profits (Rumelt, 1991; McGahan and Porter, 1997)).

${ }^{14}$ For instance, random firm effects implies that each observed firm effect is drawn randomly at some early date from an underlying population of (unobservable) possible firm effects. Once drawn, each effect is considered fixed. Note that this is different from random sampling where observations are drawn from a known underlying population.
} 
variance. The estimation problem now consists of estimating the above variance components and the parameter $\mu$ in equation (1).

For the estimation of (2), we rely on Searle's (1971) estimation of variance components in unbalanced models, underlying which is the fact that any quadratic form in observations is a linear combination of the variance components. ${ }^{15}$ For the linear model in (1), let the vector of means and the variance-covariance matrix be respectively: $\mathrm{E}(\mathbf{y})=\mu$ and $\mathbf{V}=\operatorname{var}(\mathbf{y})=\mathrm{E}(\mathbf{y}-\mu)(\mathbf{y}-\mu)^{\prime}$. The expected value under this model of the general quadratic form $\mathbf{y}^{\prime} \mathbf{Q y}$ is:

$\mathrm{E}\left(\mathbf{y}^{\prime} \mathbf{Q y}\right)=\operatorname{tr}(\mathbf{Q V})+\mu^{\prime} \mathbf{Q} \mu$

where 'tr' represents the trace operation on matrix, that of summing its diagonal elements. This result is the basis of most methods of estimating variance components from unbalanced data. The general methodology is to obtain expected values of quadratic forms from (3) and to equate them to their observed values; i.e. to equate $E$ ( $\left.\mathbf{y}^{\prime} \mathbf{Q y}\right)$ to the observed $\mathbf{y}^{\mathbf{Q}} \mathbf{Q y}$.

For instance, consider the expected value of the square of a single observation:

$$
\begin{aligned}
E\left[y_{i j k}^{2}\right] & =E\left[\mu^{2}\right]+2 E\left[\mu \alpha_{i}\right]+2 E\left[\mu \beta_{j}\right]+2 E\left[\mu \gamma_{i j}\right]+2 E\left[\mu e_{i j k}\right] \\
& +E\left[\alpha_{i}^{2}\right]+2 E\left[\alpha_{i} \beta_{j}\right]+2 E\left[\alpha_{i} \gamma_{i j}\right]+2 E\left[\alpha_{i} e_{i j k}\right] \\
& +E\left[\beta_{j}^{2}\right]+2 E\left[\beta_{j} \gamma_{i j}\right]+2 E\left[\beta_{j} e_{i j k}\right] \\
& +E\left[\gamma_{i j}^{2}\right]+2 E\left[\gamma_{i j} e_{i j k}\right] \\
& +E\left[e_{i j k}^{2}\right]
\end{aligned}
$$

Incorporating the assumptions that each of the random effects has a mean zero and that each of the effects are considered independent, the above equation reduces to

$$
\begin{aligned}
E\left[y_{i j k}^{2}\right] & =E\left[\mu^{2}\right]+E\left[\alpha_{i}^{2}\right]+E\left[\beta_{j}^{2}\right]+E\left[\gamma_{i j}^{2}\right]+E\left[e_{i j k}^{2}\right] \\
& =\mu^{2}+\sigma_{\alpha}^{2}+\sigma_{\beta}^{2}+\sigma_{\gamma}^{2}+\sigma_{e}^{2}
\end{aligned}
$$

Equation (5) shows that the expected value of the quadratic form in the observations is a linear combination of $\mu^{2}$ and the variance components.

While Rumelt (1991) and others argue that results from COV, which treats all variables symmetrically, are easier to interpret than those of the regression based approach, COV analysis is not familiar to many finance researchers. Hence we present

\footnotetext{
${ }^{15}$ See Rumelt (1991) for an excellent discussion of the COV approach including a numerical example.
} 
our initial analysis using the regression based approach and present the components of variance results in Section 4.3.

\subsection{Data}

We combine firm-level data from the World Business Environment Survey (WBES) and country-level variables from a number of different sources. The WBES surveyed firm owners and managers on their perception of the business environment in the country with questions on judiciary, corruption, regulation, taxation, competition and access to financing. The WBES was conducted in 1999-2000 and covers more than 10,000 firms in 80 countries.

The limited availability of firm-level data has prompted the increased use of surveys in corporate finance. Graham and Harvey (2001) argue that survey-based analysis offers a balance between large sample empirical analysis (that suffer from limited cross-sectional variation and restriction to quantitative data) and clinical studies, by asking very specific and qualitative questions across a broad section of firms for a moderately large sample. The WBES, in particular, has a broad scope in examining more than 200 questions in total, covering topics from property rights protection to corruption, political instability, financing constraints, regulation, business environment and government-business relationships. The survey has a reliable sampling methodology by administering the survey on a parallel basis in all the countries using a uniform methodology and parallel parameters for sample structure. To ensure uniform representation, the sample of firms surveyed was stratified on the basis of several variables like sector, size, ownership, exporters and location with the constraint that at least $15 \%$ of the firms are in each of the sub categories of these variables.

The WBES has been most recently used for its firm-level variation by Beck, Demirguc-Kunt, and Maksimovic (2005). It has also been used by Transparency International in computing its Corruption Perceptions Index for $2002^{16}$. After eliminating

\footnotetext{
${ }^{16}$ According to TI, "International surveys on perceptions serve as the most credible means of compiling a ranking of nations". See Batra, Kaufmann and Stone (2003) for a detailed analysis of the sampling methodology and findings of the survey
} 
observations with missing key data ${ }^{17}$, our sample includes 6012 firms in 62 developed and developing countries.

We measure property rights protection by survey responses to the question "I am confident that the judicial system will enforce my contractual and property rights in business disputes". Firms are asked to respond on a six point scale, with one denoting the highest level of confidence. It should be mentioned that this property rights question is not meant to capture disputes between the state and the individual.

The four firm-level variables we study, Size, Ownership, Legal Organization, and Sector are also obtained from the survey. The sample includes firms of all sizes: small firms (between 5-50 employees) represent 39\% of the sample, medium firms (51 to 500 employees) are $40 \%$ of the sample and the remaining $20 \%$ are large firms (more than 500 employees). The firms' ownership structures are classified into 9 different categories-individual, family, conglomerate group, bank, board of directors, managers, employees, government and others. We also have information on the legal organization of the company, whether it was organized as a single proprietorship, partnership, cooperative, privately-held corporation, corporation listed on a stock exchange and a other category. The firms surveyed belong to five different sectors, agriculture, manufacturing, services, construction and other.

\section{Insert Figure 1}

Figure 1 shows that there are differences in perceptions of property rights across firms with different characteristics. Overall, small-sized firms perceive their property rights as being less secure when compared to large and medium firms as shown in Figure 1a. On probing deeper, we find that there is significant variation across sizes even within the same country, i.e., holding all legal and political institutions constant. For instance, medium-sized firms in both Namibia and Nigeria respond poorest to the property rights question when compared to the small and large firms. This is consistent with recent work that shows that middle-sized firms in African countries are more severely affected than small and large firms (Sleuwaegen and Goedhuys (2002)).

\footnotetext{
${ }^{17}$ The original database consists of 10032 observations in 81 countries. We lose 2243 observations because of missing data on the dependent variables and the four firm level variables, size, ownership structure, organizational form and industry sector. On removing variables with missing institutional variables (formalism measure, democracy/autocracy, and trade), we lose 19 countries, which is about 1777 observations. This leaves us with 6012 observations in 62 countries.
} 
Figure $1 \mathrm{~b}$ shows the distribution of perceived property rights across firms with different types of owners. Firms owned by workers, followed by individual owned firms, have the lowest confidence that their property rights are going to be protected while government owned firms respond most positively. At the industry level, firms in agriculture and construction sectors have the weakest perception of property rights as shown in Figure 1c. When we look at the effect of legal status of the firm on mean property rights perception across the 62 countries (Figure 1d), we find that in general, incorporated firms perceive property rights protection to be better than firms organized as sole proprietorships and cooperatives and more so if it is a corporation listed on a stock exchange.

\subsubsection{Institutional Data}

To identify the legal origin of the country, we use data from LLSV $(1998,1999)$ who identify the legal origin of each country's Company/Commercial Law as British, French, German, Scandinavian, or Socialist. Hence we have five different dummy variables to capture each type of legal system. The British Legal Origin dummy variable takes the value 1 if the country adopted its Company/Commercial law from the British common law and zero otherwise. A similar rule is followed for constructing the dummy variables of the other legal origins. On average, firms in English common law countries respond more favorably on the property rights question than firms in French or German civil law countries.

The data on religious composition is taken from LLSV (1999) to create four dummy variables, Catholic, which takes the value 1 if Catholics are the dominant religious group in the country and 0 otherwise, Protestants, which takes the value 1 if the dominant religious group in the country is Protestants, Muslims which takes the value 1 if the dominant religious group in the country is Muslims and 0 otherwise and Other Religions which takes the value 1 if the dominant religious group in the country is not Catholics or Protestants or Muslims, and 0 if its is one of these three.

We also use data on Ethnic Fractionalization from Easterly and Levine (1997), which measures the probability that two randomly selected individuals from a country are from different ethno-linguistic groups. 
To measure geographical endowments, we use Latitude, which is the absolute value of the latitude of the country scaled between 0 and 1, from LLSV (1999). Countries closer to the equator tend to have a more tropical climate that was inhospitable to European settlers and therefore fostered "extractive" institutions. Table 1 shows that the variable Latitude varies from 0.01 for Kenya and Uganda (close to the equator) to 0.69 for Sweden. For a smaller sample of 32 countries, we use data on Settler Mortality from Acemoglu, Johnson, and Robinson (2001).

As a measure of openness of the country, we use Trade which is the extent of trade as a percentage of GDP of the country. The variable is taken from the World Development Indicators and averaged over the period 1995-99.

To capture the political view of property rights, we use variables from the Polity IV dataset, averaged over the period 1995-99 and Beck et al. (1999)'s Database of Political Institutions (DPI). The variables, Democracy and Autocracy, scored from 0-10 $(0=$ low; $10=$ high) reflect the general openness (closedness) of the political institutions in the country respectively and are from the Polity IV Dataset. According to the Polity IV Dataset, the structure of the state is determined by broadly three interdependent elementspresence of institutions and procedures through which citizens can express effective preferences about alternative policies and leaders, the existence of institutionalized constraints on the exercise of power by the executive and the guarantee of civil liberties to all citizens in their daily lives and in acts of political participation. Other aspects of democracy such as rule of law, freedom of the press and so on are regarded as specific manifestations of these general principles. The Democracy indicator is derived from codings of the competitiveness of political participation, the openness and competitiveness of executive recruitment and constraints on the chief executive. Polity IV also has a composite 11 point scale for Autocracy since many polities exhibit mixed qualities of both of these distinct authority patterns. The Autocracy score is derived from codings of the competitiveness of political participation, the regulation of participation, the openness and competitiveness of executive recruitment, and constraints on the chief executive. Checks from DPI, measures the number of influential veto players in legislative and executive initiatives. The political view predicts that greater competition 
and more checks and balances will limit the ability of the elite to dictate policy and institutional development. ${ }^{18}$

\section{Insert Table 1 and 2 here}

Table 1 lists the institutional indicators for the 62 countries in our sample. Panel A of Table 2 provides descriptive statistics and panels $\mathrm{B}$ and $\mathrm{C}$ examine correlations between the variables. The correlations between property rights and legal origin, religion, formalism, latitude, trade and democracy are all significant at the 0.01 level as shown in panel B of Table 2. The correlations between all the firm level variables and property rights are also highly significant at the $1 \%$ level.

\section{Empirical Results}

We begin with a benchmark model in which we model institutional variation at the country level with a country dummy. This specification provides us with the upper bound for the variation in firm-level responses that can be explained at the country level. We use this benchmark to interpret the results of subsequent regressions.

\section{Insert Figure 2 and Table 3 here}

The results of our analysis of variance on Equation (1) are shown in Figure 2 for the base model using country dummies and size as the firm-level characteristic. We start with the null model and successively report the effect on R-square and adjusted R-square as we add dummy variables. The model at the bottom of the figure corresponds to the fully specified model in Equation (1). Each of the lines above this model corresponds to models in which at least one class of effects has been restricted to zero. For instance, the line going left is associated with the interaction effects being restricted to zero, the line in the centre is associated with country effects being restricted to zero and the line to the right is associated with firm effects being restricted to zero. In each case, the probability level at which the F-test rejects the restriction is reported. The values show that the F-test

\footnotetext{
${ }^{18}$ In unreported tables we also used the Legislative and Executive Indices of Electoral Competiveness (LIEC/EIEC) from DPI as alternative indices in place of Democracy and Autocracy. LIEC/EIEC are narrower measures that focus specifically on the competitiveness of elections, whereas Democracy and Autocracy are more general measures of the openness (closedness) of the political system that include electoral competitiveness as one aspect. LIEC/EIEC explain a smaller proportion of property rights variation than Democracy and Autocracy.
} 
never rejects the restriction to the null-model confirming that all three types of effectscountry, firm size and interaction effects- predict how firms perceive the protection of their property rights at conventional levels of statistical significance.

Table 3 summarizes the results from Figure 2 on the increment to explanatory power by type of effect. To construct this table, we calculate the increment to R-square and adjusted R-square with effects introduced in the following order: country, firm and country-firm interactions.

Table 3 shows that the country dummies alone explain $16.51 \%$ of the variation of firm-level responses. This represents the upper bound of the proportion of the variation of perceived property rights protection that can be explained by differences in country-level institutions or other country-level effects. Knowing the size of firms has a marginal effect on explanatory power, increasing it to $16.86 \%$. Even allowing for the possibility of firms of different sizes in different countries, only increases the proportion explained to $17.93 \%$.

Figure 2 also shows the $\mathrm{R}^{2}$ obtained when starting from a regression of perceived property rights protection on firm size alone. As the figure shows, firm sizes by themselves explain $1.26 \%$ of the total variation, whereas its marginal contribution, conditional on country dummies is $0.36 \%$. Thus, $71 \%$ of the effect of firm size, ((1.26$0.36) / 1.26$ ) is subsumed by country dummies because the size distribution of firms differs across countries. The above analysis is a comparison of the explanatory power of one firm-level characteristic, size, with the upper bound of all possible country effects, some still unidentified. Below we compare the explanatory power of different country effects with specific firm-level characteristics.

\subsection{Analysis of the Full Sample}

In this section, we consider the contribution of institutional and firm level factors to adjusted R-squares when each of these factors is considered one at a time. When we look at the proposed institutional factors at the country level, legal origin explains the most variation with $4.09 \%$ followed by religion with $1.64 \%$. Apart from legal origin and religion, the other institutional factors come in insignificant explaining less than $1 \%$ of the variation in firms' perceptions of property rights protection. The poor explanatory 
power of many of the country-level variables may in part be due to non-linearities arising from the way these variables are constructed. Unlike legal origin, the other theories posit determinants of property rights that cannot be directly observed. These determinants are accordingly proxied by variables that have been independently scaled for other purposes. Thus some proxies, like legal formalism, are scaled from 0 to 7 , others like democracy are scaled from 1 to 10 . These proxies are then entered linearly in an equation that predicts a variable of interest. However, there is no reason to believe that the scales are designed to detect material effects of the determinant on the variable of interest or that, if material, the effect is likely to be linear over the range of the scale. ${ }^{19}$ We illustrate our point with the Democracy and Checks variable that represent the openness of the political system in Appendix A3.

To even the playing field, first we construct a five point scale for all the variables, based on their quantiles, to ensure the same number of categories as legal origin and then perform variance component analysis as in Table 3, using this five-point scale. In the regression, we enter dummies for each unique value of the rescaled variables.

\section{Insert Table 4 here}

Panel A of Table 4 presents the contribution to adjusted R-square when each of the re-scaled country variables are entered one at a time. The benchmark case, where country dummies are introduced for each of the countries in the sample, gives us a cap on the amount of variation that can be explained by any country level factor ${ }^{20}$. In our sample of 62 countries, country dummies explain $16.51 \%$ of the variation in firms' perceptions of how well property rights are protected. Table 4 shows that the Law and Finance view ${ }^{21}$

\footnotetext{
${ }^{19}$ There is a direct parallel with issues that arise in the testing of asset pricing models such as the CAPM. In those tests, theoretically derived constructs such as beta are usually entered directly. However, when considering variables such as firm price/earnings ratios, for which there is no direct theoretical justification and no presumption of linearity, it is customary to form portfolios of firms with similar values of price/earnings ratios, often deciles, and use dummies or analyze each decile separately.

${ }^{20}$ Note that the contribution to adjusted R-squares from the benchmark case with country dummies, legal origin, religion and the firm variables remains unchanged.

${ }^{21}$ Alternative characterizations of legal origin all yield similar results. We experimented with using only four dummies-Common law, French civil law, German and Scandinavian civil law and Socialist law, and also with using only 3 dummies-Common Law, Civil Law and Socialist Law. In the former case, the legal origin dummies explain 3.93\% and in the latter case, they explain 3.92\% confirming our result that the Law and Finance view explains the most variation in property rights. These results also hold if we were to reclassify four of the transition economies-Czech Republic and Hungary as German civil law and Bulgaria and Romania as French civil law countries instead of Socialist law, depending on their legal origin prior to 1940.
} 
holds the dominant position in terms of explaining the variation in property rights (4.09\%). Democracy score explains $3.77 \%$ followed by latitude (3.64\%), checks and balances $(2.82 \%)$ and trade $(1.87 \%)$. Religion and ethnic are somewhat similar in their explanatory power at $1.64 \%$ and $1.45 \%$ respectively. Further, latitude, trade, checks, and democracy all now explain more than any firm-level characteristic. Re-scaling the variables has significantly increased the adjusted R-squares contributed by legal formalism, latitude, democracy, autocracy, checks, trade, and ethnic fractionalization. When entered together, the institutional variables explain about $77 \%$ of the total explainable variation at the country level $(=12.76 / 16.51)$.

At the firm level, firm size by itself explains $1.22 \%$, ownership structure explains $1.76 \%$, legal organization explains $0.82 \%$ and industry sector explains $0.26 \%$, indicating that ownership structure of the company explains the most variation. These numbers indicate that in many cases, firm level characteristics are comparable to the country-level factors in their explanatory power and sometimes explain more than the institutional factors themselves. For instance, ownership structure of the company explains more than several proposed institutional determinants variables, including religion, and explains nearly $43 \%$ as much as legal origin, $47 \%$ as much as the rescaled Democracy variable and $48 \%$ as much as the rescaled Latitude variable.

Panel B of Table 4 presents the main results of the variance component analysis of Equation (1) using ANOVA. Each column in panel B of Table 4 is the analogue of the second column of Table 3 for different institutional variables. To construct Table 4, we calculated the increment to adjusted R-square with effects introduced in the following order: country, firm, and country-firm interactive effects. In each case, a figure similar to Figure 2 can be drawn for determining the contribution to the adjusted R-square.

The four sub-panels of panel B of Table 4 correspond to four different firm effects being investigated -firm size, industry sector in which the firm operates, legal organization of the company and ownership structure of the company. The country effects introduced depend on the model being tested. Comparing the firm-level effects in each column across panels, we find that ownership structure has the highest marginal contribution to adjusted R-squares confirming that ownership structure has the greatest explanatory power compared to other firm-level variables. 
For a detailed comparison of the country-firm interactions, we focus on the most significant institutional factor - legal origin. Panel A of Table 4 shows that firm size by itself explains $1.22 \%$ of the variation in property rights. However, when we include firm size in a model after legal origin as in panel B, the marginal contribution of firm size to adjusted R-squares is only $0.48 \%$. Hence, we conclude that $61 \%((1.22-0.48) / 1.22)$ of firm size effect is subsumed by legal origin because the size distribution of firms differs across countries with different legal origins. Thus, an important indirect channel through which legal origin might work is to change the size distribution of firms. Similarly, $88 \%$ of the industry effect, $79 \%$ of legal organization and $64 \%$ of the effect due to different ownership structures are subsumed within legal origin. So legal origin not only directly impacts firms' perceptions of property rights but also has an indirect impact through its effect on the distribution of different types of firms in different countries.

When we look at the joint effect of country and firm characteristics, surprisingly, the country-firm interactions are largely insignificant and come in below $1 \%$. Therefore while legal origin subsumes a large part of the size effect, there is no evidence that different legal systems affect the property rights of different firms differently. We interpret these results as suggesting that while legal origin affects the sizes of firms as they adapt to the institutions, in equilibrium, of the firms that exist once they have adapted, we don't have evidence that different legal origins treat firms of different sizes differently. On the other hand, several other institutional factors have a moderating effect on the firms. For instance, with respect to religion, religion subsumes only $11 \%$ of the firm size effect and $13 \%$ of the ownership effect but the interactive effects of religion and firm size $(0.64 \%)$ and religion and ownership (1.47\%) are not entirely negligible. In fact, the largest interactive effect across all the models is that of $1.47 \%$ implying that the predominant religious group of the country affects firms with different types of owners differently. ${ }^{22}$

\footnotetext{
${ }^{22}$ Further investigation reveals that government owned firms in Catholic countries, group owned firms in Muslim countries and manager owned firms in Protestant nations have the largest (and significant) regression coefficients, leading us to conclude that these firms have the poorest perception of property rights protection.
} 


\subsection{Without Socialist Economies}

Our sample contains a large number of transition economies. ${ }^{23}$ These economies are readily classified as having a Socialist Legal Tradition by the Legal Origin view. However, these countries differ from the rest of the countries in the sample by the very fact that they are undergoing shocks of transition and the wholesale restructuring of property rights. To the extent that the Socialist Legal Tradition also proxies for common transition shocks, the explanatory power of the legal origin view might be overstated in our tests.

To investigate if the dominance of the Law and Finance view holds when the economies undergoing transitions are excluded, Table 5 repeats the analysis in Table 4 for a smaller sample of 48 non-Socialist economies (and 4031 observations). Country dummies now explain only $12.2 \%$ of the variation in property rights as compared to $16.51 \%$ previously. The institutional factor that explains the most is now openness to trade, which explains $2.42 \%$ of the variation, followed by latitude $(2.19 \%)$, checks (1.66\%), democracy (1.61\%) and autocracy (0.89\%). Legal Origin explains only $0.87 \%$ of the total variation in firms' responses. Thus, openness to trade explains about $20 \%$ of the cross-country variation, latitude about $18 \%$, whereas legal origin only explains about $7 \%$ of the cross country variation. Taken together, all the institutional factors explain approximately $73 \%$ of the cross-country variation in this reduced sub-sample, while they explained $77 \%$ of the cross-country variation in the full sample that included the former Socialist countries.

At the firm level (not shown in the table), legal organization of the firm explains $0.6 \%{ }^{24}$ which is more than ownership structure $(0.51 \%)$. Size explains $0.35 \%$ and there is very little variation explained by the industry sector in which the firm operates $(0.03 \%)$.

\section{Insert Table 5 here}

\footnotetext{
${ }^{23}$ The transitional economies in our sample are Bulgaria, Croatia, Czech Republic, Estonia, Georgia, Hungary. Kazakhstan Lithuania, Poland, Romania, Russian Federation, Slovenia and Ukraine. China is also classified as socialist legal tradition and hence is dropped from the smaller sample.

${ }^{24}$ Ownership structure and size still do well in smaller sub-samples if we collapse the legal organization variable into four categories: sole proprietorships, partnerships, corporations and others instead of the usual six categories: sole proprietorships, partnerships, cooperatives, unlisted corporations, listed corporations, and others.
} 
When we look at the marginal contribution of the firm effects in Table 5 (second row in each panel), the maximum explanatory power across models is split between ownership and legal organization. The strongest country-firm interactive effect is that of Trade-Legal Organization $(1.13 \%){ }^{25}$

Given the strong performance of the latitude variable, we use another measure of geographical endowments, Settler Mortality, as stressed by Acemoglu, Johnson and Robinson (2001). Table 6 shows the results for a sub-set of countries for which data on settler mortality is available. The sample is now restricted to 33 countries with 2694 observations. This sample of countries is similar to the sample of non-socialist economies in Table 5.

\section{Insert Table 6 here}

We construct the table using the five point categorization applied to settler mortality. The results of Table 6 once again dramatically change the order of explanatory power of the various theories established in Table 4. The Law and Finance View is replaced by the Endowments View as the theory with the most explanatory power. Latitude now explains the most variation $(5.32 \%)$ followed by settler mortality $(3.6 \%)$. In fact, democracy $(2.56 \%)$, checks and balances $(2.25 \%)$, formalism $(2.09 \%)$, trade $(1.89 \%)$ and religion (1.04\%) all do better than legal origin $(0.54 \%)$. Together, the institutional theories explain nearly $99 \%$ of all explainable variation at the country level. At the firm level, firm size explains $0.62 \%$, firm ownership explains $0.43 \%$, legal status of the company explains $0.85 \%$ and industry sector explains $0.02 \%{ }^{26}$. So once again, in the smaller sub-set of countries, the firm's legal status explains more than ownership structure. The interaction of democracy and legal status of the company has the largest explanatory power at $2.07 \%$ which is greater than all other interactive effects across different tables. $^{27}$

\footnotetext{
${ }^{25}$ The regression coefficients reveal that corporations listed on stock exchanges in economies which are in the third quantile of countries (when countries are ranked on their openness to trade) are more likely to perceive property rights protection to be poor whereas firms that are organized as partnerships in countries that are not very open to trade (second quantile) respond favorably to the question on extent of property rights protection.

${ }^{26}$ If we were to rescale legal organization into four broad categories : Sole Proprietorships, Partnerships, Corporations and Others, the rescaled variable explains $0.30 \%$ which is less than size and ownership.

However the largest interactive effect is still that of Democracy and Legal Organization at $2.21 \%$

${ }^{27}$ Further investigation of this interactive effect reveals that corporations listed on stock exchanges in nondemocratic countries (countries in the second quantile when they are ranked on their democracy scores)
} 
Tables 5 and 6 suggest that for samples of countries not including the former Socialist economies the legal origin view has quite low power in predicting firm-level perceptions of property rights protections. As a practical matter, latitude, trade, democracy, and where available, settler mortality do a better job of predicting perceptions.

The implications of the results are less clear cut for the theories themselves. A researcher with a strong prior about the importance of legal origins would wish to include those countries in the analysis and ascribe their differences from the other countries in the sample to differences in legal origin. Such a researcher might conclude that Table 4 supports his view. A researcher with strong prior beliefs about the importance of cultural and political differences between transition economies, former colonies and West European countries may focus on the samples in Tables 5 and 6 , and reach the opposite conclusion.

Tables 4-6 reveal that there is substantial heterogeneity in the explanatory power of different institutional factors depending on the sample of countries considered. The Law and Finance view figures as the dominant theory when we consider the whole sample of 62 countries, but this effect is driven largely by the inclusion of transition economies. When we exclude the former Socialist economies, trade and latitude do well in explaining the variation in property rights giving support to the Openness to Trade and Endowments view of property rights. The Endowments view in particular comes out even stronger when we consider a smaller sample of countries for which settler mortality is available. At the firm level again, there is significant variation in the contribution of different firm characteristics to explaining the variation of property rights. While ownership structure of firms is the most significant explanatory variable in the full sample, the legal status of the firm explains more variation in property rights than other firm-level variables in the smaller sub-samples. The finding that a firm's organizational choice affects the property rights protection it receives is consistent with recent evidence

respond most favorably on the property rights question where as firms organized as partnerships in democratic countries perceive property rights protection to be the poorest. The omitted category against which this comparison is being made are firms organized as single proprietorships in non-democratic countries (lowest democracy score) 
in Demirguc-Kunt, Love and Maksimovic (2004) that organizational form of the firm impacts its access to finance and growth.

\subsection{Other Firm Perceptions and Firm Growth Rates}

In Table 7, we investigate the power of these theories in explaining firm level perceptions on judicial efficiency, corruption, taxes and regulation, financing and street crime as well as firm growth rates. A firm's perceptions on judicial efficiency, corruption and taxes and regulation are related to different aspects of the legal environment and hence are closely related to its perceptions on how secure its property rights are. The extent of property rights protection also affects the collateral put up by firms and thereby the amount of financing the firms receive. Hence one would expect firms' perceptions of property rights to be closely related to their perceptions on the extent to which Financing is an obstacle for the growth and operation of your business. In addition, we also look at street crime that could be indicative of the general status of law in the country as well a firm performance variable, firm growth rates.

\section{Insert Table 7}

Judicial Efficiency, corruption, taxes and regulation, street crime and financing are all measured by survey responses to the questions "How problematic is judicial efficiency (or corruption or taxes and regulation or street crime or financing) to the growth and operation of your business". Firms are asked to respond on a four point scale, with four denoting a major obstacle.

Panel A of Table 7 presents results for the full sample and shows that compared to the other institutional theories, the law and finance view has the greatest explanatory power in predicting variation in firms' perception of judicial efficiency (3.51\%) and taxes and regulation $(6.66 \%)$ but not so in predicting the other perception variables ${ }^{28}$. A country's endowments (Latitude) explains the most variation in firms' perception about corruption (5.48\%) while democracy explains the most variation in firms' perceptions about financing problems (4.33\%). All institutional theories together in the full sample

\footnotetext{
${ }^{28}$ Note that in terms of explainable variation at the country level, legal origin explains more of explainable variation in the case of taxes and regulation $(32 \%=6.66 / 21.07)$ and judicial efficiency $(28 \%=3.51 / 12.34)$ than in the case of property rights $(25 \%=4.09 / 16.51)$
} 
explain between $73 \%$ of the variation that can be explained at the country level in the case of street crime to $87 \%$ of the variation in firms' perceptions of judicial efficiency.

When we look at smaller sub-samples, one without transition economies and the other with only 33 countries for which data on settler mortality is available, the law and finance view completely loses its dominant position as the theory with the maximum explanatory power. A country's latitude, openness to trade and political system are the dominant theories depending on the variable being considered.

The explanatory power of legal origin in predicting the variation in firm growth rates in the full sample of countries is also much lower. This is to be expected since growth is subject to temporary shocks. Moreover, it is not an institutional characteristic such as the protection of property rights, and is less likely to be directly determined by quasi-fixed institutional factors.

In the growth regressions in the full sample, country dummies themselves explain $5.84 \%$ of the variation. The institutional variables explain less than $3.83 \%$. The three dominant variables in terms of explanatory power are latitude $(1.86 \%)$, religion $(1.18 \%)$, and legal origin $(1.04 \%)$. The other institutional variables have almost no explanatory power $^{29}$.

Across the different variables, firm characteristics have relatively low explanatory power. Panel A of Table 7 shows that ownership dummies have the maximum explanatory power in the case of taxes and regulation $(2.63 \%)$ and financing $(2.06 \%)$, legal status of the firm explains the most in the case of judicial efficiency $(1.48 \%)$ and street crime $(1.78 \%)$ and industry dummies explain the most firm level variation in the case of corruption $(0.65 \%)$ and firm growth $(0.21 \%)$. When we look at a reduced sample of countries, without the Socialist economies, legal status of the firm explains the most variation in firms' perceptions of judicial efficiency, taxes and regulation, street crime and financing.

\subsection{Estimating Variance Components}

In the analysis reported in Tables 4-7 we started by measuring the explanatory power of country factors and added firm factors, obtaining their marginal effect. For an

\footnotetext{
${ }^{29}$ The order holds for different characterizations of the legal origin variable.
} 
analysis that treats all factors symmetrically, we turn to the Components of Variance (COV) approach. As equation (5) shows, estimating the variance components using the $\mathrm{COV}$ approach involves equating the expected value of a quadratic form in the observations to their sample values and solving for $\mu^{2}$ and the variance components ${ }^{30}$. However the choice of quadratic forms that can be used is not unique (Searle 1971: 455). We select the "sum of squares" obtained from the analysis of variance (ANOVA) model for its simplicity and its consistency with the literature (Rumelt (1991)).

There are five different sum of squares that need to be calculated, one for each of the four variance components $\left(\mathrm{T}_{\alpha}, \mathrm{T}_{\beta}, \mathrm{T}_{\gamma}, \mathrm{T}_{\mathrm{e}}\right)$ and the overall sum of squares, $\mathrm{T}_{0}$, which is the sum of squared values of each observation of the dependent variable. Let $n_{i j k}=1$ if a firm $k$ belongs to size-class $j$, and is located in country $i$. We adopt the standard notation in variance component analysis that a dot represents summation over the subscript in that position. For instance, $\mathrm{n}_{\mathrm{ij}}$. is the total number of firms in country $i$ in size class $j$. Similarly the total number of observations in the sample (6012) will be given as $\mathrm{N}=\mathrm{n}$... The equations for the sums-of-squares are shown below:

$$
T_{0}=\sum_{i, j, k} y_{i j k}^{2}, T_{\mu}=\frac{y_{\ldots}^{2}}{N}, T_{\alpha}=\sum_{i} \frac{y_{i . . .}^{2}}{n_{i . .}}, T_{\beta}=\sum_{j} \frac{y_{. j .}^{2}}{n_{. j .}} \text {, and } T_{\gamma}=\sum_{i, j} \frac{y_{i j .}^{2}}{n_{i j .}}
$$

Expressions for the expected values of the quadratic forms are obtained by substituting for y from Equation (1) in the above set of equations and taking expectations $^{31}$. This gives us a set of 5 simultaneous equations in 5 unknowns as shown in Equation (7) below.

\footnotetext{
${ }^{30}$ The components of variance approach is not very well developed for non-linear models because of the complexity involved in estimating more than one random effect. Hence we present the results of the COV approach only for the linear model case. However the consistency of the simultaneous ANOVA for linear and non-linear models makes us confident that the results for the non-linear model using the COV approach would be very similar to the estimations of the linear model.

${ }^{31}$ Note that $E\left(\alpha_{i} \alpha_{j}\right)=\sigma_{\alpha}{ }^{2}$ if $i=j$ and 0 otherwise. Also expectations of cross-products between effects are all zero because of the independence assumption.
} 


$$
\begin{aligned}
& E\left[T_{0}\right]=N \mu^{2}+N \sigma_{\alpha}^{2}+N \sigma_{\beta}^{2}+N \sigma_{\gamma}^{2}+N \sigma_{e}^{2} \\
& E\left[T_{\mu}\right]=N \mu^{2}+\frac{1}{N} \sum_{i} n_{i . .} \sigma_{\alpha}^{2}+\frac{1}{N} \sum_{j} n_{. j .} \sigma_{\beta}^{2}+\frac{1}{N} \sum_{i, j} n_{i j .} \sigma_{\gamma}^{2}+\sigma_{e}^{2} \\
& E\left[T_{\alpha}\right]=N \mu^{2}+N \sigma_{\alpha}^{2}+\sum_{i}\left[\frac{\sum_{j} n_{i j .}^{2}}{n_{i . .}}\right]\left(\sigma_{\beta}^{2}+\sigma_{\gamma}^{2}\right)+l_{\alpha} \sigma_{e}^{2} \\
& E\left[T_{\beta}\right]=N \mu^{2}+N \sigma_{\beta}^{2}+\sum_{j}\left[\frac{\sum_{i} n_{i j .}^{2}}{n \cdot j .}\right]\left(\sigma_{\alpha}^{2}+\sigma_{\gamma}^{2}\right)+l_{\beta} \sigma_{e}^{2} \\
& E\left[T_{\gamma}\right]=N \mu^{2}+N \sigma_{\alpha}^{2}+N \sigma_{\beta}^{2}+N \sigma_{\gamma}^{2}+l_{\gamma} \sigma_{e}^{2}
\end{aligned}
$$

Solving this system of equations gives us solutions to the variance components, $\mu^{2}, \sigma_{\alpha}^{2}, \sigma_{\beta}^{2}, \sigma_{\gamma}^{2}$, and $\sigma_{\varepsilon}^{2}$ and thereby an estimate of the country and firm effects in determining property rights protection.

This approach may also be implemented by using procedures like PROC VARCOMP or PROC MIXED for variance component analysis in the statistical software package SAS. We verify our results from solving the sets of equations for variance components using the TYPE1 method in PROC VARCOMP and find them to be identical $^{32}$.

\section{Insert Table 8 here}

Table 8 presents the results of the variance components analysis. The analysis is performed for 62 countries and each of the variables is on a five point-scale scale (except religion which is on a four point scale) as in Table 4. Similar to the other tables, we have four panels, one for each type of the firm effect being investigated-firm size, industry, legal organization and ownership type. Each panel consists of eleven columns to test for the eleven different country-level factors being investigated. In each panel, we also compute the R-square from the variance components to show the correspondence between this type of analysis and the original R-square analysis shown in Table $4^{33}$. The

\footnotetext{
${ }^{32}$ The TYPE1 method in each of these packages corresponds to using "sum of squares" as the quadratic form and the analysis is identical to the one detailed in this section.

${ }^{33} \mathrm{R}$-square is given by [1-Var (residual in the model being investigated)/Var (residual in a model with only the intercept) $]^{*} 100$.
} 
numbers corresponding to each effect is the variance component due to that effect represented as a percentage of total variance ${ }^{34}$.

The variance component analysis confirms that legal origin is the most dominant theory in explaining the variation in property rights $(5.5-5.81 \%)$ followed by democracy score (4.88-5.14\%) and latitude (4.19\%-4.29\%). This pattern is consistent with that reported in Table 4. When we look at the firm-level effects, firm size and ownership structure explain more variation than industry and legal organization of the firm ${ }^{35}$. The Rsquares calculated in Table 8 are identical to the ones in Tables 5.

\subsection{Robustness Tests for Non-linearity}

In this section we examine whether estimating a non-linear model makes a difference to the explanatory power of the different theories. We also examine the implications of the different theories for firm growth rather than their perceptions of property rights. In both cases, we perform our analysis on the full sample of 62 countries.

The traditional linear model estimated in the tables 4-7 takes the form $\mu=X \beta$, where $\mu=\mathrm{E}(\mathrm{y})$ with $\mathrm{y}$ being the vector of observations, $\mathrm{X}$ the matrix of covariates and $\beta$ the vector of regression coefficients. It is assumed that the random effects and the error terms have a distribution which has a constant variance independent of the value of the mean of the response variable, y. To estimate a non-linear model that recognizes that $\mathrm{y}$ is bounded, we have to allow for the random effects to enter into the conditional mean in a non-linear fashion, which is accomplished by the model in equation (8) below.

The dependent variable in this study (property rights variable) is an ordered response variable with six categories $(K=6)$ representing firms' perceptions of property rights. The model most suited for an ordinal dependent variable such as this is the proportional odds model which is a natural extension of the logistic regression model from binary response to ordinal response with more than two categories.

\footnotetext{
${ }^{34}$ Note that the variance component attributed to the country varies from model to model unlike the Rsquare analysis of Tables 5-7. This is because of the following reason: The variance component analysis is based on the premise that the model being estimated is a true model. The differing variance contribution attributed to the country effect in each model arises from ignored covariance terms.

${ }^{35}$ The negative variance components are a characteristic of the data and can be considered to be either a result of model-misspecification or that the variance is actually zero. See Searle et. al (1992: 60-62) for more discussion on negative variance components and how to deal with them.
} 
$\log \left(\frac{\sum_{j=1}^{K} \pi_{j}}{1-\sum_{j=1}^{K} \pi_{j}}\right)=\alpha+\beta X$

where $\pi_{\mathrm{k}}$ is the probability that category $\mathrm{j}$ of the response variable is being picked by a firm.

For the simultaneous ANOVA approach, one point of concern with the logistic regression is that the pseudo $\mathrm{R}$-square statistic produced by a logistic regression is no longer a good estimate of the explanatory power of the model. However, recent research has shown that the McKelvey and Zavoina (1975) R-square analogue seems most conducive to comparability across different types of empirical models. In fact DeMaris (2002) finds the McKelvey and Zavoina R-square to be the best at estimating explained variance in a study comparing eight R-square analogues ${ }^{36}$.

When the analysis in Tables 4-7 is repeated using the logistic regression model described above, we find that none of the material results are changed. In the full sample with unscaled variables, on the basis of the MZ R-square statistic, legal origin explains the most variation with $4.4 \%$ followed by religion with $1.7 \%{ }^{37}$. Most of the other factors come in insignificant explaining less than $1 \%$ of the variation in firms' perceptions of property rights protection. At the firm level, firm size by itself explains $1.3 \%$, ownership structure explains $2 \%$, legal organization explains $0.9 \%$ and industry sector explains $0.4 \%$, indicating that ownership structure of the company explains the most variation.

\section{Insert Table 9}

Table 9 presents the variance analysis on the re-scaled variables using the MZ Rsquare statistic. Consistent with the results in the linear estimation in Table 4, we find that while the Law and Finance view continues to hold the dominant position in terms of

\footnotetext{
${ }^{36}$ De Maris (2002) distinguishes between the ordered response variable, y being a proxy for an underlying, unobserved continuous variable, or latent scale, $\mathrm{y}^{*}$ and the response variable y actually representing a qualitative change in state with no continuous underlying referent. For the former case (which applies to the property rights variable in this study), De Maris recommends that the MZ R-square become the standard estimator of explained variance. In fact, he states "The analyst employing $\mathrm{MZ}-\mathrm{R}^{2}$ can therefore be confident that, at least in large samples, it will, on average be closer to $\rho^{2}$ (explained variance) than any of the other measures.."

${ }^{37}$ Note that Legal Origin is still the dominant theory when we rescale legal origin into 3 categories: Common Law, Civil Law and Socialist Law Countries instead of the usual 5 categories: Common Law, French Civil Law, German Civil Law, Scandinavian Civil Law and Socialist Law.
} 
explaining the variation in property rights, religion is no longer the second-most important explanatory variable. Latitude now explains 3.8\% followed by democracy score $(3.6 \%)$, checks and balances $(2.8 \%)$ and trade $(1.9 \%)$. Religion and ethnic are somewhat similar in their explanatory power at $1.7 \%$ and $1.5 \%$ respectively. Firm ownership structure continues to explain more than the institutional variables in the case of legal formalism, ethnic, and autocracy. The slight difference between the linear estimation and the non-linear analysis in Table 9 arises from the absence of convergence in some models when the interactive effects are also included. In the smaller sample of countries too (results not shown), we find results consistent with the linear estimation. Latitude $(5.6 \%)$ and settler mortality $(3.6 \%)$ replace legal origin $(0.7 \%)$ as the variables with the most explanatory power.

\section{Conclusion}

This paper assesses the contribution of firm and country level factors to firms' perceptions of property rights protection. Using variance decomposition methodology, we examine how much of the variation in firms' perceptions of property rights can be attributed to firm characteristics, such as size, ownership structure, industrial sector and organizational form, and how much to country level institutional variables. Specifically at the country level, we compare the explanatory power of five different theories- Law and Finance, Culture and Ethnic Diversity, Endowment view, Openness to Trade theory and Political view of property rights protection.

The Law and Finance theory predicts that countries which follow the British common law tradition offer better protection of property rights than countries which follow either Civil law or Socialist law traditions. Further the theory predicts that countries whose judicial systems have a low level of procedural formalism are better safeguards of private property rights. The Culture and Ethnic diversity view predicts that property rights protection is determined by cultural variables like religion and by the ethno-linguistic fractionalization of the society. The Endowment view predicts that initial natural endowments like geography and disease environment that European colonizers faced, affected the kind of institutions they set up in the colonies. Therefore a 
country's natural endowments affect firms' perceptions of property rights protection through their effect on establishment of a country's legal institutions. The Openness to Trade theory argues that countries that are more open to international trade are better protectors of private property rights since openness to trade affects institutional development. Finally, the Political view of property rights predicts that countries that are more democratic and have higher checks and balances in their political system offer better property rights protection to firms.

At the country level, we find that for the full sample of 62 countries, the total explainable variation in firms' perceptions of property rights is capped at $16.5 \%$ by the use of country dummies. Of this, legal origin accounts for nearly $25 \%$ of the total explainable variation followed by democracy and latitude which explain $23 \%$ and $22 \%$ respectively of the total explainable variation. Together, all the institutional theories explain about $77 \%$ of the explainable cross-country variation.

However, the dominance of the Legal Origin theory in explaining property rights variation depends critically on sample selection. Removing the former Socialist economies and China or using a smaller sample of countries for which data on settler mortality is available reduces the explanatory power of the Law and Finance view significantly. In a sample of 48 non-Socialist economies, Legal Origin and Religion explain less than $10 \%$ of the total explainable variation in firms' perceptions. However in this reduced sample, the Openness to Trade view and the Endowment view explain nearly $20 \%$ and $18 \%$ of the total variation in firms' perceptions of property rights.

When we examine a broader set of variables related to property rights we also find that once we exclude the former Socialist countries, legal origin explains very little of the variation in perceptions of judicial efficiency, corruption, taxes and regulation, street crime and financing. This is significant because the critical distinction in LLSV $(1998,1999)$ is between common law and civil law, not between former Socialist and other countries.

Proponents of the endowments view argue that initial endowments shape a country's institutions. To the extent that we find that measures of initial endowments explain the variation of property rights better than specific proxies for institutions, our results suggest either that there are other unidentified channels by which endowments 
influence property rights or that the proxies in current use do not measure the underlying institutions well.

When we compare the firm level factors versus the above discussed institutional theories, we find that firm level variables, specifically size, ownership structure and organizational form are comparable in their explanatory power to the different theories. For instance, comparing the firm variables to legal origin, the country variable with the highest explanatory power, ownership structure explains $43 \%$ as much as legal origin, size explains $30 \%$ as much as legal origin and organizational form explains $20 \%$ as much as legal origin.

We also find that the firm level characteristics are in turn endogenously determined by the country level factors which decreases their explanatory power when put together in a single equation along with country level variables, masking their true importance.

The paper shows that scaling of variables matters for the explanatory power of different theories. While the matter has been mostly ignored in the finance literature, this paper shows that there are significant non-linearities arising from the way some variables are scaled, which in turn affects their explanatory power. For instance, on rescaling variables like democracy and checks, that represent the Political View, we find that the variables' contribution to the total variation in firms perceptions about property rights increases by a factor of ten.

When we look at how well the different theories explain other firm level variables like sales growth, we find that the law and finance view is the third most dominant theory, albeit with lower explanatory power-it explains $18 \%$ of the total explainable variation in firms' sales growth as compared to $25 \%$ of the variation in firms' perceptions of property rights protection. This is not surprising since the property rights question is institutional whereas growth may depend on other transitory factors.

Finally this paper provides a new methodology for estimating the importance of different country-level and firm-level factors in explaining the variation in property rights. The components of variance approach used in the paper is supportive of the regression based analysis of variance results. The intuitive appeal of this approach lends itself to use in examining other questions in finance and economics. 


\section{References}

Acemoglu, D., 2003. The Form of Property Rights: Oligarchic vs. Democratic Societies. Unpublished working paper.

Acemoglu, D., Johnson, S., 2003. Unbundling Institutions. MIT Department of Economics Working Paper No. 03-29.

Acemoglu, D., Johnson, S., Robinson, J. A., 2001. The Colonial Origins of Comparative Development: An empirical investigation. American Economic Review 91, 1369-1401.

Acemoglu, D., Johnson, S., Robinson, J. A., 2002. Reversal of fortunes: Geography and Institutions in the making of the modern world income distribution. Quarterly Journal of Economics 117 (4), 1231-1294.

Ayyagari, M., 2004. Does Cross-Listing Lead to Functional Convergence? Empirical Evidence. World Bank Working Paper Series No. 3264.

Ayyagari, M., Demirgüç-Kunt, A., Maksimovic, V., 2005. How Important Are Financing Constraints? The role of finance in the business environment. World Bank mimeo.

Batra, G., Kaufmann, D., Stone, A., 2003. The Firms Speak: What the World Business Environment Survey Tells Us about Constraints on Private Sector Development. World Bank mimeo.

Beck, T., Clarke, G., Groff, A., Keefer, P., Walsh, P., 2001. New tools and new tests in comparative political economy: the database of political institutions. World Bank Economic Review 15, 165- 176.

Beck, T., Demirgüç-Kunt, A., Levine, R., 2003. Law, Endowments, and Finance. Journal of Financial Economics 70 (2), 137-181.

Beck, T., Demirgüç-Kunt, A., Maksimovic, V., 2005. Financial and Legal Constraints to Firm Growth: Does Firm Size Matter. Journal of Finance 60, 137-179.

Beck, T., Demirgüç-Kunt, A., Laeven, L., Maksimovic, V., 2005. The Determinants of Financing Obstacles. Journal of International Money and Finance forthcoming.

Beck, T., Demirgüç-Kunt, A., Levine, R., 2005. Law and Firms’ Access to Finance. American Law and Economics Review, forthcoming.

Beck, T., Levine, R., 2002. Industry growth and capital allocation: Does Having a Market- or Bank Based System Matter? Journal of Financial Economics 64, 147-180. 
Burkart, M., Panunzi, F., and Shleifer, A., 2003, Family Firms. Journal of Finance 58, 2173-2207.

Claessens, S., Fan, J.P.H., 2002. Corporate Governance in Asia: A Survey. International Review of Finance 3, 71-103.

Claessens, S., Laeven, L., 2003. Financial Development, Property Rights, and Growth. Journal of Finance, 58 (6), 2401-2436.

DeMaris, A. (2002). Explained Variance in Logistic Regression. A Monte Carlo Study of Proposed Measures. Sociological Methods \& Research 31(1), 27-74.

Demirgüç-Kunt, A., Love, I., Maksimovic, V., 2004 Business Environment and the Incorporation Decision, World Bank Working Paper.

Demirgüç-Kunt, A., Maksimovic, V., 1998. Law, finance, and firm growth, Journal of Finance 53, 2107-2137.

Demirgüç-Kunt, A., Maksimovic, V., 1999. Institutions, Financial Markets and Firm Debt Maturity, Journal of Financial Economics 54(3).

Djankov, S., La Porta, R., Lopez-de-Silanes, F., Shleifer, A., 2003. Courts. Quarterly Journal of Economics, 118 (2), 453-517.

Doidge, C., Karolyi, A., and Stulz, R., 2004. Why are Foreign Firms Listed In the U.S. Worth More? Journal of Financial Economics 71, 205-238.

Easterly, W. Levine, R., 1997. Africa's growth tragedy: policies and ethnic divisions. Quarterly Journal of Economics 112, 1203-1250.

Engerman, S., Sokoloff, K., 1997. Factor endowments, institutions, and differential paths of growth among new world economies. In Haber, S.H. (Ed.), How Latin America Fell Behind, Stanford University Press, Stanford CA, pp. 260-304.

Fisman, R., Khanna, T., 2004. Facilitating Development: The Role of Business Groups. World Development 32 (4), 609-628.

Friedman, E., Johnson, S., Mitton, T., 2003. Propping and Tunneling. Journal of Comparative Economics 31 (4), 732-750.

Glaeser, E., Shleifer, A., 2002. Legal origins. Quarterly Journal of Economics 117 (4), 1193-1290.

Graham, J.R., Harvey, C. R., 2001. The Theory and Practice of Corporate Finance: Evidence from the Field. Journal of Financial Economics 60, 187-243. 
Himmelberg, C., Hubbard, R. G., and Love, I., 2002. Investor Protection, Ownership, and the Cost of Capital. World Bank Working Paper Series No. 2834.

Jensen, M. and Meckling, W., 1976. Theory of the Firm: Managerial behavior, agency costs and ownership structure. Journal of Financial Economics 3, 305-360.

Jinks, J. L., and Fulker, D. W.,1970. Comparison of the biometrical genetical, MAVA, and classical approaches to the analysis of human behavior. Psychological Bulletin 73, 311-349.

Johnson, S., Boone, P., Breach, A., Friedman, E., 2000. Corporate Governance in the Asian Financial Crisis. Journal of Financial Economics 58, 141-186.

Johnson, S., La Porta, R., Lopez-de-Silanes, F., Shleifer. A., 2000. Tunneling. American Economic Review 90, 22 -27.

Khanna, T., Rivkin, J., 2001. Estimating the Performance Effects of Business Groups in Emerging Markets. Strategic Management Journal 22, (1), 45-74.

Kumar, K., Rajan, R., Zingales, L., 2002. What Determines Firm Size? Working paper, University of Chicago GSB.

La Porta, R., Lopez-de-Silanes, F., 1999. The Benefits of Privatization: Evidence from Mexico. Quarterly Journal of Economics 114 (4).

La Porta, R., Lopez-de-Silanes, F., Shleifer, A., Vishny, R.W., 1997. Legal determinants of external finance. Journal of Finance 52, 1131-1150.

La Porta, R., Lopez-de-Silanes, F., Shleifer, A., Vishny, R.W., 1998. Law and finance. Journal of Political Economy 106, 1113-1155

La Porta, R., Lopez-de-Silanes, F., Shleifer, A., Vishny, R.W., 1999. The Quality of Government. Journal of Law, Economics, and Organization 15, 222-279.

La Porta, R., Lopez-de-Silanes, F., Shleifer, A., Vishny, R.W., 1999b. Corporate Ownership Around the World. Journal of Finance, 54, 471-517.

La Porta, R., Lopez-de-Silanes, F., Shleifer, A., Vishny, R.W., 2000. Investor protection and corporate governance. Journal of Financial Economics 58, 3-27.

La Porta, R., Lopez-de-Silanes, F., Shleifer, A., Vishny, R.W., 2000b. Agency Problems and Dividend Policies Around the World. Journal of Finance 55 (1), 1-33.

La Porta, R., Lopez-de-Silanes, F., Shleifer, A., Vishny, R.W., 2002. Investor Protection and Corporate Valuation. Journal of Finance 57, 1147-1170. 
Laeven, L., Woodruff, C., 2004. The Quality of the Legal System and Firm Size. SSRN Working Paper Series.

Love, I., Mylenko, N., 2003. Credit Reporting and Financing Constraints. World Bank Working Paper \# 3142.

McGahan, A. M., Porter, M.E., 1997. How Much Does Industry Matter, Really? Strategic Management Journal 18, 15-30.

McGahan, A. M., Porter, M.E., 2002. What Do We Know About Variance in Accounting Profitability? Management Science 48 (7), 834-851.

McKelvey, R. D., Zavoina, W., 1975. A Statistical Model for the Analysis of Ordinal Dependent Variables. Journal of Mathematical Sociology 4, 103-20.

Menard, S., 1995. Applied Logistic Regression Analysis. Sage University Paper Series on Quantitative Applications in the Social Sciences, 07-106. Thousand Oaks, CA: Sage.

Morck, R., Yeung, B.,Yu, W., 2000. The Information Content of Stock Markets: Why do Emerging Markets have Synchronous Price Movements? Journal of Financial Economics $58,215-260$.

Morck, R.,Wolfenzon, D., Yeung, B.,2004. Corporate Governance, Economic Entrenchment and Growth. NBER Working Paper 10692.

North D., 1990. Institutions, Institutional Change and Economic Performance; Cambridge University Press, Cambridge

Olson, M.,1993. Dictatorship, Democracy and Development; American Political Science Review 87, 567-76

Rajan, R.G., Zingales, L., 2003. The great reversals: The politics of financial development in the twentieth century. Journal of Financial Economics, 69 (1), 5-50.

Rumelt, R., 1991. How Much Does Industry Matter? Strategic Management Journal 12 (3), 167-185.

Schmalensee, R., 1985. Do Markets Differ Much? American Economic Review 75 (3), 341-351.

Searle, S., 1971. Linear Models. John Wiley \& Sons, Inc., New York, NY.

Searle, S., Casella, G., McCulloch, C. E., 1992. Variance Components. John Wiley \& Sons, Inc., New York, NY. 
Sleuwaegen, L., and Goedhuys, M., 2002. Growth of firms in developing countries, evidence from Cote d'Ivoire. Journal of Development Economics 68, 117-35.

Stulz, R., Williamson, R. 2003. Culture, Openness and Finance. Journal of Finance 70 (3), 313-49.

Stulz, R., Karolyi, A., Doidge, C., 2004. Why Do Countries Matter So Much for Corporate Governance? NBER Working Paper 10726.

Wolfenzon, D., 1999. A theory of pyramidal ownership. Unpublished working paper. Harvard University Press: Cambridge, MA.

Wooldridge, J. M., 2003. Introductory Econometrics: A Modern Approach, 2e. Thomson South-Western publication.

Wurgler, J., 2000. Financial Markets and the Allocation of Capital. Journal of Financial Economics 58,187-214. 
Figure 1a: Distribution of Property Rights Across Firm Sizes

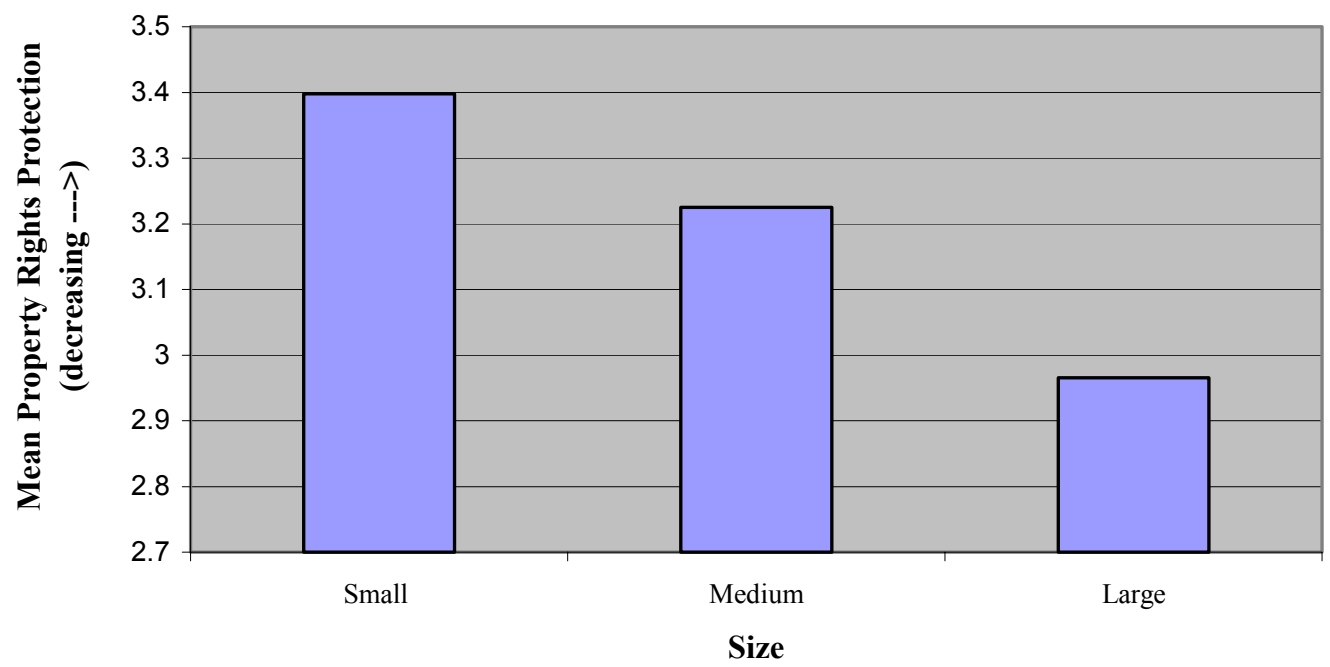

Figure 1b: Distribution of Property Rights Across Ownership Types

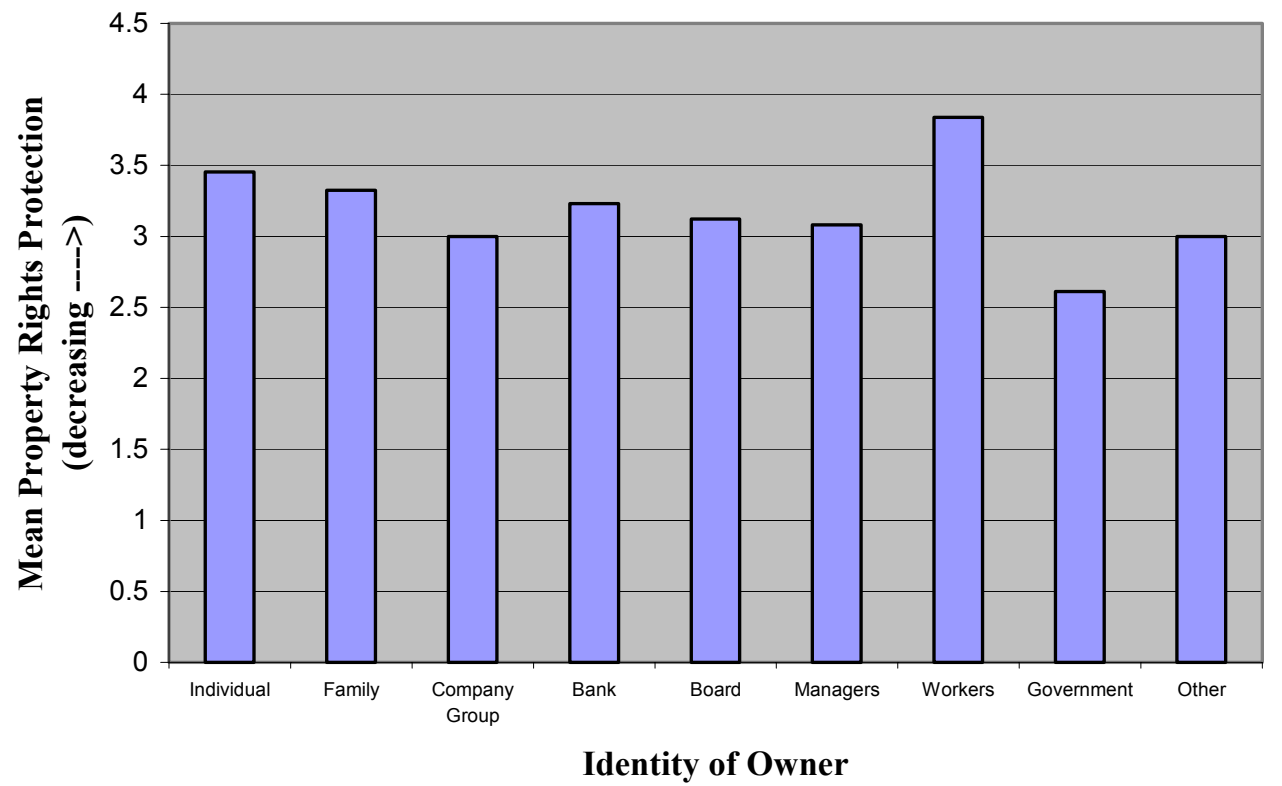


Figure 1c: Distribution of Property Rights Across Different Industries

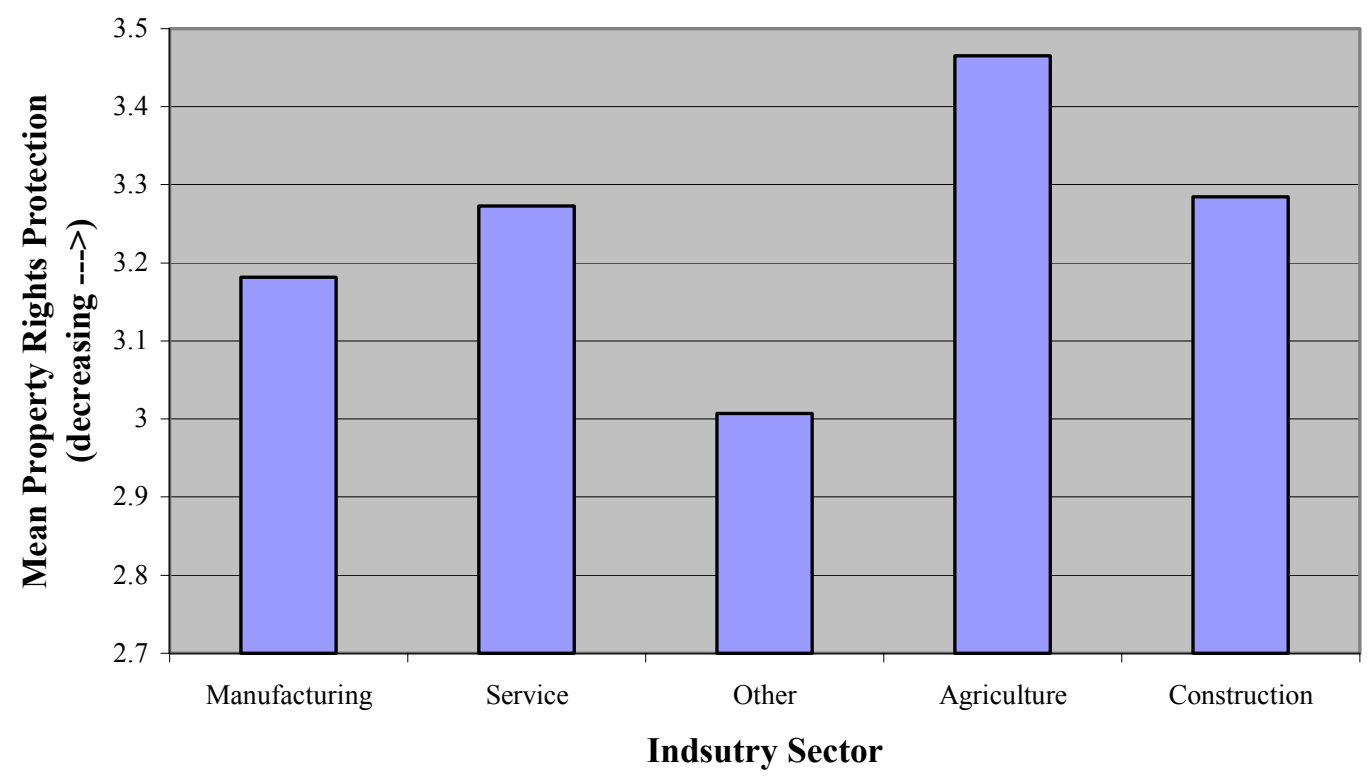

Figure 1d: Distribution of Property Rights Across Organization Structures

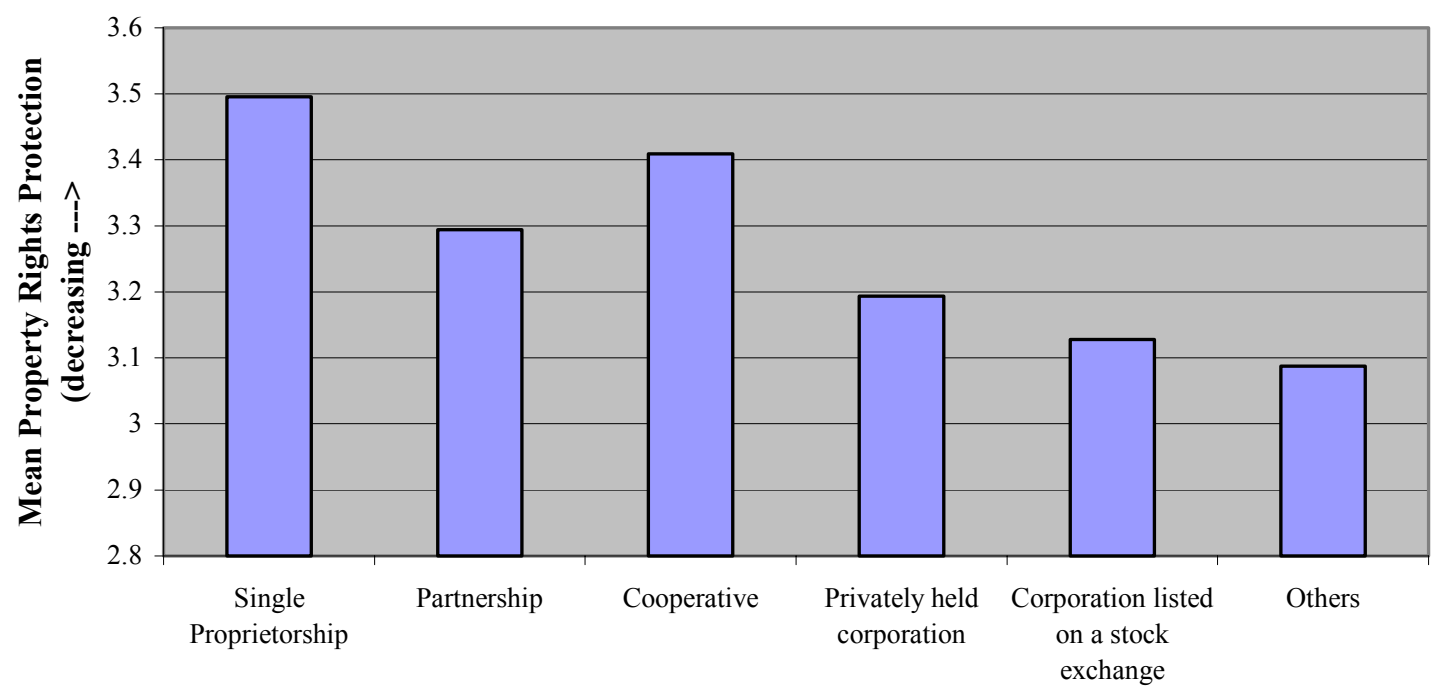

Firm Organization 


\section{Figure 2: Explaining Firms' Perception of Property Rights Protection}

The regression model estimated is Property Rights $=$ constant + Firm size dummies $(F)+$ Country dummies $(C)+$ Country Dummies*Firm size dummies (FC). The R-squares and adjusted R-squares are reported below each model specification. The arrows represent the model in which the class of effects at the base of the arrow is restricted to be zero. All p-values of the F-test of each individual restriction are 0.0000 .

Null Model

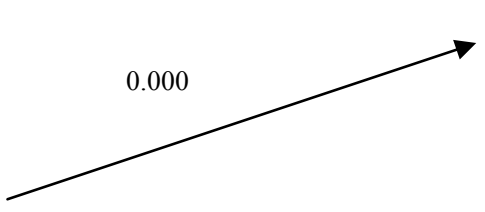

F Only

$\mathrm{R}^{2}=0.0126$

Adj $R^{2}=0.0122$

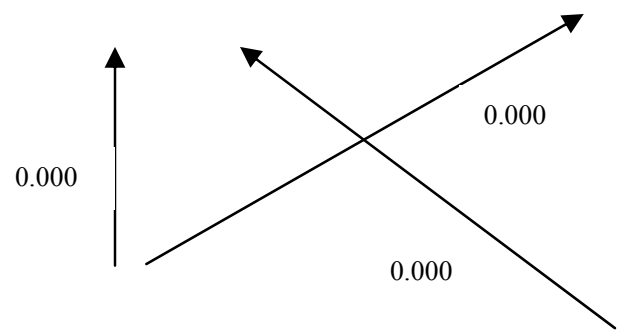

\section{4}

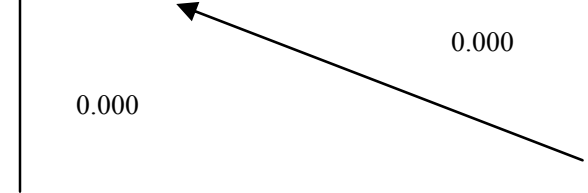

C Only

$\mathrm{R}^{\frac{\mathrm{C}}{2}=0.1736}$

Adj $R^{2}=0.1651$

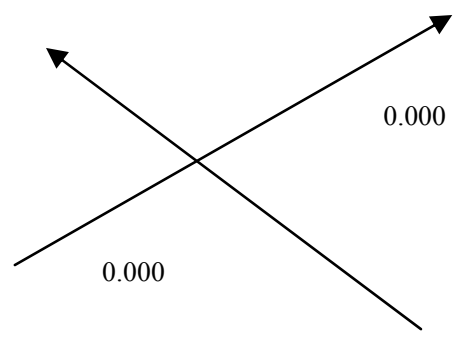

FC Effects

$\mathrm{R}^{2}=0.1307$

Adj $R^{2}=0.1127$
$\underline{\mathbf{F}+\mathbf{C}}$

$\mathrm{R}^{2}=0.1773$

Adj $R^{2}=0.1686$

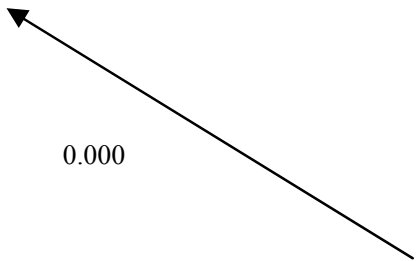

$\mathbf{F}+\mathbf{F C}$

$\mathrm{R}^{2}=0.1308$

Adj $R^{2}=0.1125$

C+FC

$\mathrm{R}^{2}=0.2035$

Adj $R^{2}=0.1785$

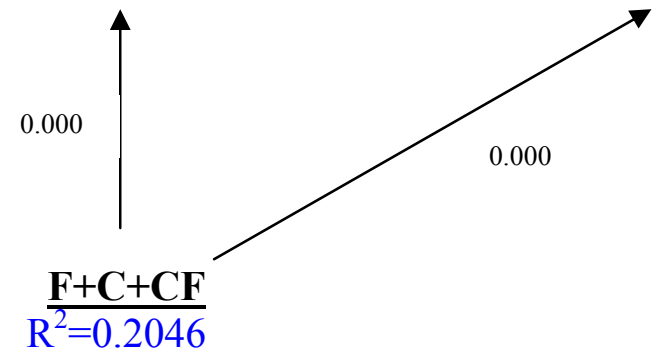

Adj $R^{2}=0.1793$ 


\section{Table 1: Summary Statistics}

The variables are described as follows: Legal Origin takes the value 1 if it is a Common-Law country, 2 if it French civil-law, 3 if it is German civil law, 4 if it is Scandinavian law and 5 it is Socialist Law. Legal Formalism is a measure of procedural formalism in connection with collecting a bounced check, Religion takes one of four different values depending on whether the dominant religious group in the country are Catholics, Protestants, Muslims or Other, Ethnic Fractionalization is the probability that two randomly selected individuals in a country will not speak the same language. Latitude is the absolute value of the latitude of the country scaled between zero and one. Trade is the sum of exports and imports as a fraction of GDP. Checks measures the number of veto-players in the political decision process. Democracy is a measure of the openness of the political system while autocracy is a measure of closedness of the political system. Detailed variable definitions and sources are given in the appendix.

\begin{tabular}{|c|c|c|c|c|c|c|c|c|c|}
\hline nation & Legal Origin & Formalism & Religion & $\begin{array}{l}\text { Ethnic } \\
\text { Fractionalization }\end{array}$ & Latitude & Trade & Checks & Democracy & Autocracy \\
\hline Argentina & 2 & 5.40 & 1.00 & 0.18 & 0.38 & 21.83 & 2.80 & 7.20 & 0.00 \\
\hline Bangladesh & 1 & 3.24 & 3.00 & 0.00 & 0.27 & 30.29 & 4.00 & 6.00 & 0.00 \\
\hline Bulgaria & 5 & 4.57 & 4.00 & 0.12 & 0.48 & 99.42 & 2.40 & 8.00 & 0.00 \\
\hline Bolivia & 2 & 5.96 & 1.00 & 0.60 & 0.19 & 49.30 & 4.00 & 9.00 & 0.00 \\
\hline Brazil & 2 & 3.06 & 1.00 & 0.06 & 0.11 & 18.17 & 5.20 & 8.00 & 0.00 \\
\hline Botswana & 1 & 4.08 & 4.00 & 0.38 & 0.24 & 94.51 & 3.60 & 8.60 & 0.00 \\
\hline Canada & 1 & 2.09 & 1.00 & 0.38 & 0.67 & 77.88 & 3.60 & 10.00 & 0.00 \\
\hline Chile & 2 & 4.57 & 1.00 & 0.05 & 0.33 & 57.64 & 3.60 & 8.00 & 0.00 \\
\hline China & 5 & 3.41 & 4.00 & 0.23 & 0.39 & 41.53 & 1.00 & 0.00 & 7.00 \\
\hline Colombia & 2 & 4.11 & 1.00 & 0.06 & 0.04 & 35.84 & 2.40 & 7.00 & 0.00 \\
\hline Costa Rica & 2 & 5.48 & 1.00 & 0.05 & 0.11 & 88.08 & 4.00 & 10.00 & 0.00 \\
\hline Czech Republic & 5 & 4.06 & 4.00 & 0.32 & 0.55 & 116.75 & 5.60 & 10.00 & 0.00 \\
\hline Germany & 3 & 3.51 & 2.00 & 0.04 & 0.57 & 53.49 & 4.40 & 10.00 & 0.00 \\
\hline Dominican Republic & 2 & 4.05 & 1.00 & 0.01 & 0.21 & 66.19 & 4.60 & 7.40 & 0.00 \\
\hline Ecuador & 2 & 4.92 & 1.00 & 0.33 & 0.02 & 52.43 & 3.60 & 8.80 & 0.00 \\
\hline Egypt, Arab Republic & 2 & 3.79 & 3.00 & 0.02 & 0.30 & 44.74 & 2.00 & 0.80 & 4.40 \\
\hline Spain & 2 & 5.25 & 1.00 & 0.27 & 0.44 & 51.18 & 4.00 & 10.00 & 0.00 \\
\hline Estonia & 5 & 4.36 & 2.00 & 0.51 & 0.66 & 159.08 & 4.00 & 7.00 & 1.00 \\
\hline France & 2 & 3.23 & 1.00 & 0.15 & 0.51 & 47.07 & 4.60 & 9.00 & 0.00 \\
\hline United Kingdom & 1 & 2.58 & 4.00 & 0.11 & 0.60 & 56.35 & 3.60 & 10.00 & 0.00 \\
\hline Georgia & 5 & 3.09 & 4.00 & 0.49 & 0.47 & 56.21 & 3.00 & 6.00 & 1.00 \\
\hline Ghana & 1 & 2.65 & 4.00 & 0.71 & 0.09 & 75.47 & 3.00 & 2.60 & 1.20 \\
\hline Guatemala & 2 & 5.68 & 1.00 & 0.48 & 0.17 & 43.48 & 2.20 & 7.20 & 0.20 \\
\hline Honduras & 2 & 4.90 & 1.00 & 0.10 & 0.17 & 97.53 & 2.00 & 6.20 & 0.00 \\
\hline
\end{tabular}




\begin{tabular}{|c|c|c|c|c|c|c|c|c|c|}
\hline nation & Legal Origin & Formalism & Religion & $\begin{array}{l}\text { Ethnic } \\
\text { Fractionalization }\end{array}$ & Latitude & Trade & Checks & Democracy & Autocracy \\
\hline Croatia & 5 & 3.62 & 1.00 & 0.37 & 0.50 & 90.98 & 2.00 & 0.00 & 5.00 \\
\hline Hungary & 5 & 3.42 & 1.00 & 0.07 & 0.52 & 110.82 & 3.00 & 10.00 & 0.00 \\
\hline Indonesia & 2 & 3.90 & 4.00 & 0.69 & 0.06 & 64.27 & 1.00 & 1.60 & 5.40 \\
\hline India & 1 & 3.34 & 4.00 & 0.74 & 0.22 & 23.62 & 11.60 & 9.00 & 0.00 \\
\hline Italy & 2 & 4.04 & 1.00 & 0.04 & 0.47 & 48.75 & 3.20 & 10.00 & 0.00 \\
\hline Kazakhstan & 5 & 4.76 & 4.00 & 0.62 & 0.53 & 74.79 & 1.00 & 1.00 & 5.00 \\
\hline Kenya & 1 & 3.09 & 4.00 & 0.83 & 0.01 & 63.90 & 3.00 & 1.20 & 4.40 \\
\hline Lithuania & 5 & 4.47 & 1.00 & 0.32 & 0.62 & 108.99 & 3.00 & 10.00 & 0.00 \\
\hline Mexico & 2 & 4.71 & 1.00 & 0.17 & 0.26 & 61.56 & 2.80 & 5.20 & 0.00 \\
\hline Malawi & 1 & 2.95 & 2.00 & 0.62 & 0.15 & 65.32 & 4.00 & 7.00 & 0.00 \\
\hline Malaysia & 1 & 2.34 & 3.00 & 0.61 & 0.03 & 197.32 & 3.60 & 4.00 & 1.00 \\
\hline Namibia & 1 & 3.82 & 2.00 & 0.73 & 0.24 & 105.29 & 1.00 & 6.00 & 0.00 \\
\hline Nigeria & 1 & 3.09 & 4.00 & 0.86 & 0.11 & 78.14 & 1.00 & 1.00 & 4.50 \\
\hline Pakistan & 1 & 3.76 & 3.00 & 0.62 & 0.33 & 35.53 & 5.80 & 6.00 & 1.20 \\
\hline Panama & 2 & 5.84 & 1.00 & 0.19 & 0.10 & 69.52 & 4.00 & 9.00 & 0.00 \\
\hline Peru & 2 & 5.60 & 1.00 & 0.43 & 0.11 & 31.74 & 2.00 & 3.00 & 2.00 \\
\hline Philippines & 2 & 5.00 & 1.00 & 0.72 & 0.14 & 98.46 & 2.20 & 8.00 & 0.00 \\
\hline Poland & 5 & 4.15 & 1.00 & 0.04 & 0.58 & 54.80 & 4.00 & 9.00 & 0.00 \\
\hline Portugal & 2 & 3.93 & 1.00 & 0.00 & 0.44 & 68.36 & 2.80 & 10.00 & 0.00 \\
\hline Romania & 5 & 4.42 & 4.00 & 0.12 & 0.51 & 61.02 & 6.80 & 7.40 & 0.00 \\
\hline Russian Federation & 5 & 3.39 & 4.00 & 0.25 & 0.67 & 55.11 & 4.60 & 5.00 & 1.00 \\
\hline Senegal & 2 & 4.72 & 3.00 & 0.78 & 0.16 & 68.21 & 2.00 & 2.00 & 3.00 \\
\hline El Salvador & 2 & 4.60 & 1.00 & 0.05 & 0.15 & 59.51 & 4.00 & 7.00 & 0.00 \\
\hline Slovenia & 5 & 4.26 & 1.00 & 0.22 & 0.51 & 112.99 & 5.00 & 10.00 & 0.00 \\
\hline Sweden & 4 & 2.98 & 2.00 & 0.07 & 0.69 & 74.82 & 3.20 & 10.00 & 0.00 \\
\hline Thailand & 1 & 3.14 & 4.00 & 0.36 & 0.17 & 95.14 & 5.40 & 9.00 & 0.00 \\
\hline Trinidad and Tobago & 1 & 1.80 & 4.00 & 0.23 & 0.12 & 97.96 & 4.40 & 9.60 & 0.00 \\
\hline Tunisia & 2 & 4.05 & 3.00 & 0.07 & 0.38 & 89.19 & 1.00 & 1.00 & 4.00 \\
\hline Turkey & 2 & 2.53 & 3.00 & 0.16 & 0.43 & 50.11 & 3.80 & 8.40 & 1.00 \\
\hline Tanzania & 1 & 3.82 & 3.00 & 0.89 & 0.07 & 46.47 & 2.60 & 2.00 & 3.00 \\
\hline Uganda & 1 & 2.61 & 1.00 & 0.84 & 0.01 & 33.83 & 1.00 & 0.00 & 4.00 \\
\hline
\end{tabular}




\begin{tabular}{|c|c|c|c|c|c|c|c|c|c|}
\hline nation & Legal Origin & Formalism & Religion & $\begin{array}{l}\text { Ethnic } \\
\text { Fractionalization }\end{array}$ & Latitude & Trade & Checks & Democracy & Autocracy \\
\hline Ukraine & 5 & 3.66 & 4.00 & 0.47 & 0.54 & 92.67 & 5.80 & 6.80 & 0.00 \\
\hline Uruguay & 2 & 4.05 & 1.00 & 0.07 & 0.37 & 39.30 & 3.60 & 10.00 & 0.00 \\
\hline United States & 1 & 2.62 & 2.00 & 0.21 & 0.42 & 23.95 & 4.60 & 10.00 & 0.00 \\
\hline Venezuela & 2 & 6.01 & 1.00 & 0.05 & 0.09 & 47.18 & 3.67 & 7.80 & 0.00 \\
\hline South Africa & 1 & 1.68 & 4.00 & 0.83 & 0.32 & 47.99 & 2.00 & 9.00 & 0.00 \\
\hline Zambia & 1 & 2.13 & 4.00 & 0.83 & 0.17 & 68.16 & 3.00 & 3.60 & 1.60 \\
\hline Zimbabwe & 1 & 3.11 & 4.00 & 0.60 & 0.22 & 83.99 & 2.00 & 0.00 & 6.00 \\
\hline
\end{tabular}




\section{Table 2: Summary Statistics and Correlations}

Panel A presents the summary statistics and Panel B presents the correlations. The variables are described as follows: Property Rights is the response of firms to the question "I am confident that the judicial system will enforce my contractual and property rights in business disputes", scored on a scale of 1-6 (low-high). Judicial Efficiency (Corruption) (Taxes \& Regulation) (Street Crime) (Financing) are responses of firms to the questions "How problematic is judicial efficiency (corruption) (taxes \& regulation) (street crime) (financing) to the growth and operation of your business", scored on a scale of 1-4 (not a problem-very problematic). Firm Growth is the increase in firm sales over the past three years. Firm Size takes on one of three values for small, medium and large firms, Industrial Sector could be agriculture, manufacturing, services, construction or other, Legal Organization is one of six values to reflect whether the firm is organized as a single proprietorship, partnership, cooperative, privately-held corporation, corporation listed on a stock exchange or another alternative form, and Ownership reflects whether the owner of the firm is an individual, a family, conglomerate group, bank, board of directors, managers, employees, government or other. Legal Origin takes the value 1 if it is a Common-Law country, 2 if it French civil-law, 3 if it is German civil law, 4 if it is Scandinavian law and 5 it is Socialist Law. Legal Formalism is a measure of procedural formalism in connection with collecting a bounced check, Religion takes one of four different values depending on whether the dominant religious group in the country are Catholics, Protestants, Muslims or Other, Ethnic Fractionalization is the probability that two randomly selected individuals in a country will not speak the same language. Latitude is the absolute value of the latitude of the country scaled between zero and one. Trade is the sum of exports and imports as a fraction of GDP. Checks measures the number of veto-players in the political decision process. Democracy is a measure of the openness of the political system while autocracy is a measure of closedness of the political system. Detailed variable definitions and sources are given in the appendix.

\section{Panel A:}

\begin{tabular}{|c|c|c|c|c|c|}
\hline Variable & $\mathrm{N}$ & Mean & $\begin{array}{c}\text { Standard } \\
\text { Deviation } \\
\end{array}$ & Minimum & Maximum \\
\hline \multicolumn{6}{|l|}{ Dependent Variables } \\
\hline Property Rights & 6012 & 3.24 & 1.41 & 1.00 & 6.00 \\
\hline Judicial Efficiency & 4525 & 2.15 & 1.02 & 1.00 & 4.00 \\
\hline Corruption & 5334 & 2.49 & 1.14 & 1.00 & 4.00 \\
\hline Taxes \& Regulation & 5695 & 2.98 & 0.96 & 1.00 & 4.00 \\
\hline Street Crime & 5427 & 2.45 & 1.13 & 1.00 & 4.00 \\
\hline Financing & 5607 & 2.78 & 1.11 & 1.00 & 4.00 \\
\hline Firm Growth & 4327 & 0.17 & 0.57 & -3.00 & 8.00 \\
\hline \multicolumn{6}{|l|}{ Firm Variables } \\
\hline Size & 6012 & 1.80 & 0.74 & 1.00 & 3.00 \\
\hline Ownership & 6012 & 3.42 & 2.11 & 1.00 & 9.00 \\
\hline Legal Organization & 6012 & 3.55 & 1.69 & 1.00 & 6.00 \\
\hline Industry & 6012 & 2.08 & 1.23 & 1.00 & 5.00 \\
\hline \multicolumn{6}{|l|}{ Institutional Variables } \\
\hline LegalOrigin & 6012 & 2.74 & 1.67 & 1.00 & 5.00 \\
\hline Formalism & 6012 & 3.76 & 0.96 & 1.68 & 6.01 \\
\hline Religion & 6012 & 2.50 & 1.38 & 1.00 & 4.00 \\
\hline \multicolumn{6}{|l|}{ Settler Mortality } \\
\hline Ethnic Fractionalization & 6012 & 0.34 & 0.27 & 0.00 & 0.89 \\
\hline Latitude & 6012 & 0.36 & 0.21 & 0.01 & 0.69 \\
\hline Trade & 6012 & 67.45 & 32.46 & 18.17 & 197.32 \\
\hline Checks & 6012 & 3.79 & 1.96 & 1.00 & 11.60 \\
\hline Democracy & 6012 & 6.69 & 3.19 & 0.00 & 10.00 \\
\hline Autocracy & 6012 & 1.01 & 1.80 & 0.00 & 7.00 \\
\hline
\end{tabular}




\section{Panel B:}

\begin{tabular}{|c|c|c|c|c|c|c|c|c|c|}
\hline & $\begin{array}{c}\text { Property } \\
\text { Rights }\end{array}$ & $\begin{array}{l}\text { Legal } \\
\text { Origin }\end{array}$ & Formalism & Religion & $\begin{array}{c}\text { Ethnic } \\
\text { Fractionalization }\end{array}$ & Latitude & Trade & Checks & Democracy \\
\hline Firm Growth & -0.02 & & & & & & & & \\
\hline Legal Origin & $0.19 * * *$ & & & & & & & & \\
\hline Formalism & $0.07 * * *$ & $0.20 * * *$ & & & & & & & \\
\hline $\begin{array}{l}\text { Religion } \\
\text { Ethnic }\end{array}$ & $0.07 * * *$ & $0.09 * * *$ & $-0.45 * * *$ & & & & & & \\
\hline Fractionalization & $0.02 *$ & $-0.30 * * *$ & $-0.21 * * *$ & $0.40^{* * *}$ & & & & & \\
\hline Latitude & $0.10^{* * *}$ & $0.73 * * *$ & $-0.09 * * *$ & $0.11^{* * *}$ & $-0.36 * * *$ & & & & \\
\hline Trade & $-0.04 * * *$ & $0.24 * * *$ & -0.01 & $0.10^{* * *}$ & $0.14 * * *$ & $0.13^{* * *}$ & & & \\
\hline Checks & -0.01 & 0.02 & $-0.10 * * *$ & $0.20 * * *$ & $-0.04 * * *$ & $0.13 * * *$ & $-0.16^{* * *}$ & & \\
\hline Democracy & $-0.08 * * *$ & 0.01 & $0.10^{* * *}$ & $-0.34 * * *$ & $-0.44 * * *$ & $0.26^{* * *}$ & 0.02 & $0.47 * * *$ & \\
\hline Autocracy & $0.03 * *$ & 0.01 & $-0.12 * * *$ & $0.31 * * *$ & $0.38 * * *$ & $-0.18 * * *$ & -0.02 & $-0.49 * * *$ & $-0.89 * * *$ \\
\hline
\end{tabular}

$*, * *$ and $* * *$ represent significance at the 10,5 and $1 \%$ levels respectively

\section{Panel C:}

\begin{tabular}{|c|c|c|c|c|}
\hline & Property Rights & Firm Size & Industry Sector & $\begin{array}{c}\text { Legal } \\
\text { Organization }\end{array}$ \\
\hline Firm Size & $-0.11 * * *$ & & & \\
\hline Industry Sector & $0.03 * *$ & $-0.12 * * *$ & & \\
\hline Legal Organization & $-0.09 * * *$ & $0.37 * * *$ & $-0.07 * * *$ & \\
\hline Ownership Structure & $0.10^{* * *}$ & $0.34 * * *$ & $-0.06 * * *$ & $0.37 * * *$ \\
\hline
\end{tabular}




\section{Table 3: Increment to explanatory power by Type of Effect-Benchmark Case}

This table documents the contribution of each effect to the adjusted R-square of the regression model. The regression model is Property Right $\mathrm{s}_{\mathrm{ij}}=$ Country Dummies $_{\mathrm{i}}+$ Firm Size $_{\mathrm{j}}+(\text { Country Dummies * Firm Size })_{\mathrm{ij}}$. The variables are defined as follows: Property rights is a firm response variable scored 1 to 6 to the survey question "I am confident that the judicial system will enforce my contractual and property rights in business disputes", with 1 denoting the highest level of confidence. The country dummies take the value one for the particular country and zero otherwise. Firm Size are dummies created for Small, Medium, and Large sized firms.

R-square Adjusted R-square

Country $^{\text {a }}$

$17.36 \%$

$16.51 \%$

Firm Size ${ }^{b}$

Interactions ${ }^{c}$

Total

20.46

17.93

\footnotetext{
${ }^{a}$ Increment in model of country effects over null model

${ }^{\mathrm{b}}$ Increment in model of country and firm effects over model of country effects

${ }^{\mathrm{c}}$ Increment in full model of country, firm and interaction effects over model of country and firm effects
} 
Table 4: Determinants of Firms' Perception of Property Rights Protection -Rescaled Variable Dummies

Panel A documents the contribution of the firm level variables and the re-scaled country level variables to the adjusted R-square of the regression model when they are entered one at a time. Panel B presents the variance component analysis by including country, firm and interaction effects. The regression model in Panel B is Property Rights $\mathrm{s}_{\mathrm{ij}}=\mathrm{Country}_{\mathrm{Effect}}+\mathrm{Firm}_{\mathrm{ize}}$ (or Industry Sector (or $_{\mathrm{j}}$

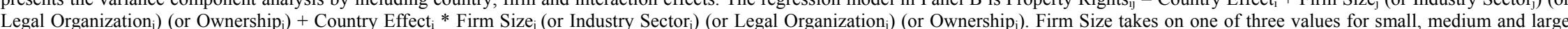
firms, Industrial Sector could be agriculture, manufacturing, services, construction or other, Legal Organization is one of six values to reflect whether the firm is organized as a single proprietorship, partnership, cooperative, privately-held corporation, corporation listed on a stock exchange or another alternative form, and Ownership reflects whether the owner of the firm is an individual, a family, conglomerate group, bank, board of directors, managers, employees, government or other. In each regression, the country effect is captured by one of the following variables at the country level: Country Dummies, Legal Origin, Legal Formalism, Religion, Ethnic Fractionalization, Latitude, Trade, Checks and Balances, Autocracy and Democracy. The variables are defined as follows: Legal Origin takes one of five possible values for the five different legal traditions: English Common Law, French Civil Law, German Civil Law, Scandinavian Civil Law and Socialist law, Legal Formalism is a measure of procedural formalism in connection with collecting a bounced check, Religion takes one of four different values depending on whether the dominant religious group in the country are Catholics, Protestants, Muslims or Other, Ethnic Fractionalization is the probability that two randomly selected individuals in a country will not speak the same language. Latitude is the absolute value of the latitude of the country scaled between zero and one. Trade is the sum of exports and imports as a fraction of GDP. Checks measures the number of veto-players in the political decision process. Democracy is a measure of the openness of the political system while autocracy is a measure of closedness of the political system. Legal Formalism, Ethnic Fractionalization, Latitude, Trade, Checks and Balances, Autocracy and Democracy are rescaled on a five point scale. Dummy variables are used for the all the country and firm variables. Detailed variable definitions and sources are given in the appendix.

\begin{tabular}{lc}
\hline \multicolumn{2}{l}{ Panel A: Contribution to Adjusted R-Squares } \\
\hline Rescaled Institutional Variables & Property Rights \\
\hline Country Dummies & 16.51 \\
Legal Origin Dummies & $\mathbf{4 . 0 9}$ \\
(Rescaled) Legal Formalism & 0.61 \\
Religion Dummies & 1.64 \\
(Rescaled) Ethnic & 1.45 \\
(Rescaled) Latitude & 3.64 \\
(Rescaled) Trade & 1.87 \\
(Rescaled) Checks and Balances & 2.82 \\
(Rescaled) Democracy & 3.77 \\
(Rescaled) Autocracy & 1.3 \\
All Institutional Theories Together & 12.76 \\
\hline Firm Variables & \\
\hline Size Dummies & 1.22 \\
Industry Dummies & 0.26 \\
Legal Organization Dummies & 0.82 \\
Ownership Dummies & $\mathbf{1 . 7 6}$ \\
All Firm Variables Together & 2.29 \\
\hline
\end{tabular}




\begin{tabular}{|c|c|c|c|c|c|c|c|c|c|c|c|}
\hline \multicolumn{12}{|c|}{ Panel B: Country, Firm and Interaction Effects } \\
\hline & \multirow{2}{*}{$\begin{array}{l}\text { I. } \\
\text { Benchmark } \\
\\
\text { Country } \\
\text { Dummy } \\
\end{array}$} & \multicolumn{2}{|c|}{ II: Law and Finance } & \multicolumn{2}{|c|}{$\begin{array}{l}\text { III: Culture and } \\
\text { Ethnic Diversity }\end{array}$} & \multirow{2}{*}{$\begin{array}{l}\text { IV: } \\
\text { Endowments } \\
\\
\quad \text { Latitude } \\
\end{array}$} & \multirow{2}{*}{$\begin{array}{l}\begin{array}{l}V: \\
\text { Openness } \\
\text { to Trade }\end{array} \\
\\
\quad \text { Trade } \\
\end{array}$} & \multicolumn{3}{|c|}{ VI: Political View } & \multirow[t]{2}{*}{$\begin{array}{l}\text { VII: All } \\
\text { Institutional } \\
\text { Theories } \\
\text { Together } \\
\end{array}$} \\
\hline & & $\begin{array}{c}\text { Legal } \\
\text { Origin } \\
\text { Dummies }\end{array}$ & $\begin{array}{c}\text { Legal } \\
\text { Formalism }\end{array}$ & Religion & Ethnic & & & $\begin{array}{c}\text { Checks } \\
\text { and } \\
\text { Balances }\end{array}$ & Democracy & Autocracy & \\
\hline \multicolumn{12}{|l|}{ Firm Size } \\
\hline Country & 16.51 & 4.09 & 0.61 & 1.64 & 1.45 & 3.64 & 1.87 & 2.82 & 3.77 & 1.3 & 12.76 \\
\hline Size & 0.35 & 0.48 & 1.36 & 1.08 & 0.89 & 0.62 & 1.29 & 1.01 & 1.08 & 1.03 & 0.53 \\
\hline Interactions & 1.07 & 0 & 0.32 & 0.64 & 0.05 & 0.34 & 0.24 & 0.59 & -0.02 & 0.01 & 1.2 \\
\hline Total & 17.93 & 4.57 & 2.29 & 3.36 & 2.39 & 4.6 & 3.4 & 4.42 & 4.83 & 2.34 & 14.49 \\
\hline \multicolumn{12}{|l|}{ Industry } \\
\hline Country & 16.51 & 4.09 & 0.61 & 1.64 & 1.45 & 3.64 & 1.87 & 2.82 & 3.77 & 1.3 & 12.76 \\
\hline Industrial Sector & 0.02 & 0.03 & 0.22 & 0.19 & 0.12 & 0.02 & 0.16 & 0.08 & 0.15 & 0.18 & -0.01 \\
\hline Interactions & 0.77 & 0.09 & 0.47 & 0.51 & 0.29 & 0.33 & 0.36 & 0.25 & 0.01 & 0.06 & 1.06 \\
\hline Total & 17.3 & 4.21 & 1.3 & 2.34 & 1.86 & 3.99 & 2.39 & 3.15 & 3.93 & 1.54 & 13.81 \\
\hline \multicolumn{12}{|l|}{ Organizational Form } \\
\hline Country & 16.51 & 4.09 & 0.61 & 1.64 & 1.45 & 3.64 & 1.87 & 2.82 & 3.77 & 1.3 & 12.76 \\
\hline Legal Organization & 0.34 & 0.17 & 1.1 & 0.87 & 0.69 & 0.35 & 0.94 & 0.93 & 0.78 & 0.64 & 0.53 \\
\hline Interactions & 1.28 & 0.37 & 0.35 & 0.68 & 1.33 & 0.84 & 1.01 & 0.45 & 0.67 & 0.24 & 2.34 \\
\hline Total & 18.13 & 4.63 & 2.06 & 3.19 & 3.47 & 4.83 & 3.82 & 4.2 & 5.22 & 2.18 & 15.63 \\
\hline \multicolumn{12}{|l|}{ Ownership } \\
\hline Country & 16.51 & 4.09 & 0.61 & 1.64 & 1.45 & 3.64 & 1.87 & 2.82 & 3.77 & 1.3 & 12.76 \\
\hline Ownership & 0.28 & 0.64 & 1.67 & 1.53 & 1.39 & 1.07 & 1.56 & 1.23 & 1.43 & 1.57 & 0.53 \\
\hline Interactions & 0.76 & 0.61 & 0.96 & 1.47 & 1.42 & 0.49 & 0.98 & 0.7 & 0.13 & -0.05 & 1.39 \\
\hline Total & 17.55 & 5.34 & 3.24 & 4.64 & 4.26 & 5.2 & 4.41 & 4.75 & 5.33 & 2.82 & 14.68 \\
\hline
\end{tabular}




\section{Table 5: Determinants of Firms' Perception of Property Rights Protection -Without Socialist Economies}

This table documents the contribution of each effect to the adjusted R-square of the regression model. The regression model in Panel A(B)(C)(D) is Property Rights $\mathrm{i}_{\mathrm{ij}}=\mathrm{Country}_{\mathrm{Effect}}+\mathrm{Firm}_{\mathrm{i}} \mathrm{Size}_{\mathrm{j}}\left(\right.$ or $_{\mathrm{i}}$ Industry Sector $\mathrm{j}_{\mathrm{j}}$ (or Legal Organization $\left.\mathrm{j}_{\mathrm{j}}\right)\left(\right.$ or Ownership $\left._{\mathrm{j}}\right)+$ Country Effect $_{\mathrm{i}} *$ Firm Size $_{\mathrm{j}}\left(\right.$ or Industry Sector $\left._{\mathrm{j}}\right)\left(\right.$ or Legal Organization $\left._{\mathrm{j}}\right)\left(\right.$ or Ownership $\left._{\mathrm{j}}\right)$. Firm Size takes on one of three values for small, medium and large firms, Industrial Sector could be agriculture, manufacturing, services, construction or other, Legal Organization is one of six values to reflect whether the firm is organized as a single proprietorship, partnership, cooperative, privately-held corporation, corporation listed on a stock exchange or another alternative form, and Ownership reflects whether the owner of the firm is an individual, a family, conglomerate group, bank, board of directors, managers, employees, government or other. In each regression, the country effect is captured by one of the following variables at the country level: Country Dummies, Legal Origin, Legal Formalism, Religion, Ethnic Fractionalization, Latitude, Trade, Checks and Balances, Autocracy and Democracy. The variables are defined as follows: Legal Origin takes one of five possible values for the five different legal traditions: English Common Law, French Civil Law, German Civil Law, Scandinavian Civil Law and Socialist law, Legal Formalism is a measure of procedural formalism in connection with collecting abounced checks, Religion takes one of four different values depending on whether the dominant religious group in the country are Catholics, Protestants, Muslims or Other, Ethnic Fractionalization is the probability that two randomly selected individuals in a country will not speak the same language. Latitude is the absolute value of the latitude of the country scaled between zero and one. Trade is the sum of exports and imports as a fraction of GDP. Checks measures the number of veto-players in the political decision process. Democracy is a measure of the openness of the political system while autocracy is a measure of closedness of the political system. Legal Formalism, Ethnic Fractionalization, Latitude, Trade, Checks and Balances, Autocracy and Democracy are rescaled on a five point scale. Dummy variables are used for the all the country and firm variables. Detailed variable definitions and sources are given in the appendix.

\begin{tabular}{|c|c|c|c|c|c|c|c|c|c|c|c|}
\hline & \multirow{2}{*}{$\begin{array}{c}\text { I:Benchmark } \\
\\
\text { Country } \\
\text { Dummy }\end{array}$} & \multicolumn{2}{|c|}{ II: Law and Finance } & \multicolumn{2}{|c|}{$\begin{array}{l}\text { III: Culture and Ethnic } \\
\text { Diversity }\end{array}$} & \multirow{2}{*}{$\begin{array}{l}\text { IV: } \\
\text { Endowments } \\
\\
\text { Latitude }\end{array}$} & \multirow{2}{*}{$\begin{array}{l}\text { V: } \\
\text { Openness } \\
\text { to Trade } \\
\\
\quad \text { Trade } \\
\end{array}$} & \multicolumn{3}{|c|}{ VI: Political View } & \multirow[t]{2}{*}{$\begin{array}{l}\text { VII: All Institutional } \\
\text { Theories Together }\end{array}$} \\
\hline & & $\begin{array}{c}\text { Legal } \\
\text { Origin } \\
\text { Dummies } \\
\end{array}$ & $\begin{array}{c}\text { Legal } \\
\text { Formalism } \\
\end{array}$ & Religion & Ethnic & & & $\begin{array}{c}\text { Checks } \\
\text { and } \\
\text { Balances }\end{array}$ & Democracy & Autocracy & \\
\hline \multicolumn{12}{|l|}{ Panel A: } \\
\hline Country & 12.2 & 0.87 & 0.84 & 0.78 & 0.77 & 2.19 & 2.42 & 1.66 & 1.61 & 0.89 & 8.93 \\
\hline Size & 0.25 & 0.46 & 0.42 & 0.45 & 0.41 & 0.35 & 0.43 & 0.43 & 0.34 & 0.32 & 0.35 \\
\hline Interactions & 1.41 & 0.01 & 0.35 & 0.26 & 0.37 & 0.48 & 0.16 & 0.66 & 0.2 & 0.03 & 1.37 \\
\hline Total & 13.86 & 1.34 & 1.61 & 1.49 & 1.55 & 3.02 & 3.01 & 2.75 & 2.15 & 1.24 & 10.65 \\
\hline \multicolumn{12}{|l|}{ Panel B: } \\
\hline Industrial Sector & 0.04 & -0.01 & 0.02 & 0 & 0.11 & 0.02 & 0 & 0.09 & 0.27 & 0.2 & 0.1 \\
\hline Interactions & 0.65 & 0.15 & 0.41 & 0.12 & 0.18 & 0.72 & 0.75 & 0.28 & 0.14 & 0.04 & 1.02 \\
\hline Total & 12.89 & 1.01 & 1.27 & 0.9 & 1.06 & 2.93 & 3.17 & 2.03 & 2.02 & 1.13 & 10.05 \\
\hline \multicolumn{12}{|l|}{ Panel C: } \\
\hline Country & 12.2 & 0.87 & 0.84 & 0.78 & 0.77 & 2.19 & 2.42 & 1.66 & 1.61 & 0.89 & 8.93 \\
\hline Legal Organization & 0.1 & 0.33 & 0.55 & 0.47 & 0.61 & 0.39 & 0.62 & 0.68 & 0.45 & 0.62 & 0.27 \\
\hline Interactions & 1.7 & 0.03 & 0.69 & 0.47 & 0.84 & 1.07 & 1.13 & 0.91 & 0.33 & 0.15 & 3.77 \\
\hline Total & 14 & 1.23 & 2.08 & 1.72 & 2.22 & 3.65 & 4.17 & 3.25 & 2.39 & 1.66 & 12.97 \\
\hline \multicolumn{12}{|l|}{ Panel D: } \\
\hline Country & 12.2 & 0.87 & 0.84 & 0.78 & 0.77 & 2.19 & 2.42 & 1.66 & 1.61 & 0.89 & 8.93 \\
\hline Ownership & 0.21 & 0.34 & 0.43 & 0.39 & 0.58 & 0.56 & 0.4 & 0.73 & 0.78 & 0.7 & 0.33 \\
\hline Interactions & 0.92 & 0.19 & 0.51 & 0.52 & 0.76 & 0.78 & 0.78 & 0.45 & 0.26 & -0.09 & 1.02 \\
\hline Total & 13.33 & 1.4 & 1.78 & 1.69 & 2.11 & 3.53 & 3.6 & 2.84 & 2.65 & 1.5 & 10.28 \\
\hline
\end{tabular}




\section{Table 6: Determinants of Firms' Perception of Property Rights Protection -33 Countries}

This table documents the contribution of each effect to the adjusted R-square of the regression model. The regression model in Panel A(B)(C)(D) is Property Rights $\mathrm{s}_{\mathrm{ij}}=$ Country Effect $_{\mathrm{i}}+\mathrm{Firm}_{\mathrm{iz}} \mathrm{Siz}_{\mathrm{j}}$ (or

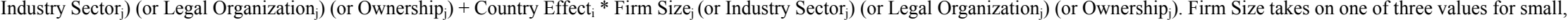
medium and large firms, Industrial Sector could be agriculture, manufacturing, services, construction or other, Legal Organization is one of six values to reflect whether the firm is organized as a single proprietorship, partnership, cooperative, privately-held corporation, corporation listed on a stock exchange or another alternative form, and Ownership reflects whether the owner of the firm is an

individual, a family, conglomerate group, bank, board of directors, managers, employees, government or other. In each regression, the country effect is captured by one of the following variables at the country level: Country Dummies, Legal Origin, Legal Formalism, Religion, Ethnic Fractionalization, Settler Mortality, Latitude, Trade, Checks and Balances, Autocracy and Democracy. The variables are defined as follows: Legal Origin takes one of five possible values for the five different legal traditions: English Common Law, French Civil Law, German Civil Law, Scandinavian Civil Law and Socialist law, Legal Formalism is a measure of procedural formalism in connection with collecting a bounced check, Religion takes one of four different values depending on whether the dominant religious group in the country are Catholics, Protestants, Muslims or Other. Ethnic Fractionalization is the probability that two randomly selected individuals in a country will not speak the same language. Settler Mortality is the $\log$ of the annualized deaths per thousand European soldiers in European colonies in the early $19^{\text {th }}$ century.Latitude is the absolute value of the latitude of the country scaled between zero and one. Trade is the sum of exports and imports as a fraction of GDP. Checks measures the number of veto-players in the political decision process. Democracy is a measure of the openness of the political system while autocracy is a measure of closedness of the political system. Legal Formalism, Ethnic Fractionalization, Settler Mortality, Latitude, Trade, Checks and Balances, Autocracy and Democracy are rescaled on a five point scale. Dummy variables are used for the all the country and firm variables. Detailed variable definitions and sources are given in the appendix.

\begin{tabular}{|c|c|c|c|c|c|c|c|c|c|c|c|c|}
\hline & \multirow{2}{*}{$\begin{array}{l}\begin{array}{l}\text { I: } \\
\text { Benchmark } \\
\text { case }\end{array} \\
\\
\text { Country } \\
\text { Dummy } \\
\end{array}$} & \multicolumn{2}{|c|}{$\begin{array}{l}\text { II: Law and Finance } \\
\text { View }\end{array}$} & \multicolumn{2}{|c|}{$\begin{array}{l}\text { III: Culture-Ethnic } \\
\text { Diversity }\end{array}$} & \multicolumn{2}{|c|}{ IV: Endowments } & \multirow{2}{*}{$\begin{array}{l}\begin{array}{l}\text { V: } \\
\text { Openness } \\
\text { to Trade }\end{array} \\
\\
\quad \text { Trade } \\
\end{array}$} & \multicolumn{3}{|c|}{ VI: Political View } & \multirow[t]{2}{*}{$\begin{array}{l}\text { VII: All } \\
\text { Institutional } \\
\text { Theories } \\
\text { Together } \\
\end{array}$} \\
\hline & & $\begin{array}{c}\text { Legal } \\
\text { Origin } \\
\text { Dummies } \\
\end{array}$ & $\begin{array}{c}\text { Legal } \\
\text { Formalism } \\
\end{array}$ & Religion & Ethnic & $\begin{array}{c}\text { Settler } \\
\text { Mortality } \\
\end{array}$ & Latitude & & $\begin{array}{c}\text { Checks } \\
\text { and } \\
\text { Balances }\end{array}$ & Democracy & Autocracy & \\
\hline \multicolumn{13}{|l|}{ Panel A: } \\
\hline Country & 13.82 & 0.54 & 2.08 & 1.04 & 0.83 & 3.6 & 5.32 & 1.89 & 2.25 & 2.56 & 0.78 & 13.84 \\
\hline Size & 0.24 & 0.71 & 0.87 & 0.74 & 0.56 & 0.47 & 0.3 & 0.59 & 0.62 & 0.45 & 0.5 & 0.23 \\
\hline Interactions & 1.58 & 0.06 & 0.54 & 0.35 & 0.14 & 0.07 & 0.98 & -0.04 & 1 & 0.02 & 0.12 & 1.57 \\
\hline Total & 15.64 & 1.31 & 3.49 & 2.13 & 1.53 & 4.14 & 6.6 & 2.44 & 3.87 & 3.03 & 1.4 & 15.64 \\
\hline \multicolumn{13}{|l|}{ Panel B: } \\
\hline Country & 13.82 & 0.54 & 2.08 & 1.04 & 0.83 & 3.6 & 5.32 & 1.89 & 2.25 & 2.56 & 0.78 & 13.84 \\
\hline Industrial Sector & -0.09 & -0.01 & 0.11 & 0.02 & 0.15 & 0.01 & -0.07 & 0.09 & 0.08 & 0.04 & 0.05 & -0.09 \\
\hline Interactions & -0.1 & 0.33 & 0.55 & 0.03 & 0.11 & 0.25 & 0.09 & 0.29 & 0.09 & 0.11 & -0.03 & -0.12 \\
\hline Total & 13.63 & 0.86 & 2.74 & 1.09 & 1.09 & 3.86 & 5.34 & 2.27 & 2.42 & 2.71 & 0.8 & 13.63 \\
\hline \multicolumn{13}{|l|}{ Panel C: } \\
\hline Country & 13.82 & 0.54 & 2.08 & 1.04 & 0.83 & 3.6 & 5.32 & 1.89 & 2.25 & 2.56 & 0.78 & 13.84 \\
\hline Legal Organization & 0.06 & 0.61 & 0.76 & 0.73 & 1.1 & 0.35 & 0.11 & 0.61 & 0.82 & 0.52 & 0.88 & 0.05 \\
\hline Interactions & 1.62 & 0.15 & 0.43 & 0.68 & 1.1 & 0.46 & 1.35 & 1.01 & 1.76 & 2.07 & 0.67 & 1.61 \\
\hline Total & 15.5 & 1.3 & 3.27 & 2.45 & 3.03 & 4.41 & 6.78 & 3.51 & 4.83 & 5.15 & 2.33 & 15.5 \\
\hline \multicolumn{13}{|l|}{ Panel D: } \\
\hline Country & 13.82 & 0.54 & 2.08 & 1.04 & 0.83 & 3.6 & 5.32 & 1.89 & 2.25 & 2.56 & 0.78 & 13.84 \\
\hline Ownership & -0.05 & 0.25 & 0.32 & 0.24 & 0.65 & 0.37 & 0.24 & 0.36 & 0.68 & 0.53 & 0.6 & -0.05 \\
\hline Interactions & 0.57 & 0.79 & 0.78 & 0.9 & 0.68 & 0.36 & 0.57 & 0.45 & 0.35 & 0.31 & 0.17 & 0.55 \\
\hline Total & 14.34 & 1.58 & 3.18 & 2.18 & 2.16 & 4.33 & 6.13 & 2.7 & 3.28 & 3.4 & 1.55 & 14.34 \\
\hline
\end{tabular}


Table 7: Determinants of Firms' Growth Rates and their Perception of Business Obstacles

The table documents the contribution of the firm level variables and the re-scaled country level variables to the adjusted R-square of the regression model when they are entered one at a time. Panel A presents results for the whole sample and panel B presents results for two smaller sub-samples, one without transition economies and one for 33 countries for which data on settler mortality is available. The regression model in Panel B is Crime/Corruption/Taxes \& Regulation/Financing/Growth Rate = Country Effect (or Firm Size) (or Industry Sector) (or Legal Organization) (or Ownership). Growth rate is the percentage change in the firm's sales during the last three years. Financing, Crime, Corruption and Taxes and Regulation are general obstacles as indicated in the firm questionnaire. They take values 1 to 4 , with where 1 indicates no obstacle and 4 indicates major obstacle. Firm Size takes on one of three values for small, medium and large firms, Industrial Sector could be agriculture, manufacturing, services, construction or other, Legal Organization is one of six values to reflect whether the firm is organized as a single proprietorship, partnership, cooperative, privately-held corporation, corporation listed on a stock exchange or another alternative form, and Ownership reflects whether the owner of the firm is an individual, a family, conglomerate group, bank, board of directors, managers, employees, government or other. In each regression, the country effect is captured by one of the following variables at the country level: Country Dummies, Legal Origin, Legal Formalism, Religion, Ethnic Fractionalization, Settler Mortality, Latitude, Trade, Checks and Balances, Autocracy and Democracy. The variables are defined as follows: Legal Origin takes one of five possible values for the five different legal traditions: English Common Law, French Civil Law, German Civil Law, Scandinavian Civil Law and Socialist law, Legal Formalism is a measure of procedural formalism in connection with collecting a bounced check, Religion takes one of four different values depending on whether the dominant religious group in the country are Catholics, Protestants, Muslims or Other. Ethnic Fractionalization is the probability that two randomly selected individuals in a country will not speak the same language. Settler Mortality is the log of the annualized deaths per thousand European soldiers in European colonies in the early $19^{\text {th }}$ century Latitude is the absolute value of the latitude of the country scaled between zero and one. Trade is the sum of exports and imports as a fraction of GDP. Checks measures the number of veto-players in the political decision process. Democracy is a measure of the openness of the political system while autocracy is a measure of closedness of the political system. Legal Formalism, Ethnic Fractionalization, Settler Mortality, Latitude, Trade, Checks and Balances, Autocracy and Democracy are rescaled on a five point scale. Dummy variables are used for the all the country and firm variables. Detailed variable definitions and sources are given in the appendix.

\begin{tabular}{|c|c|c|c|c|c|c|}
\hline \multicolumn{7}{|l|}{ Panel A: Full Sample } \\
\hline Country Variables & $\begin{array}{c}\text { Judicial } \\
\text { Efficiency }\end{array}$ & Corruption & $\begin{array}{l}\text { Taxes and } \\
\text { Regulation }\end{array}$ & Street Crime & $\begin{array}{c}\text { Financing } \\
\text { Obstacle }\end{array}$ & Firm Growth \\
\hline Country Dummies & 12.34 & 24.19 & 21.07 & 21.3 & 13.89 & 5.84 \\
\hline Legal Origin Dummies & 3.51 & 3.58 & 6.66 & 4 & 2.98 & 1.04 \\
\hline (Rescaled) Legal Formalism & 3.43 & 4.3 & 0.95 & 4.48 & 1.19 & 0.81 \\
\hline Religion Dummies & 2.23 & 4.6 & 1.5 & 2.2 & 4.04 & 1.18 \\
\hline (Rescaled) Ethnic & 0.68 & 3.42 & 2.74 & 2.17 & 3.27 & 0 \\
\hline (Rescaled) Latitude & 2.09 & 5.48 & 5.09 & 3.61 & 0.51 & 1.86 \\
\hline (Rescaled) Trade & 1.26 & 2.34 & 1.82 & 2.74 & 0.2 & 0.43 \\
\hline (Rescaled) Checks and Balances & 1.04 & 1.57 & 3.94 & 0.58 & 1.82 & 0.71 \\
\hline (Rescaled) Democracy & 2.37 & 5.16 & 4.67 & 4.38 & 4.33 & 0.66 \\
\hline (Rescaled) Autocracy & 0.02 & 2.37 & 1.08 & 0.07 & 2.83 & 0.54 \\
\hline All Institutional Theories Together & 10.76 & 18.47 & 15.48 & 15.47 & 10.5 & 3.83 \\
\hline \multicolumn{7}{|l|}{ Firm Variables } \\
\hline Size Dummies & 0.37 & -0.04 & 1.02 & 0.15 & 1.34 & 0.02 \\
\hline Ownership Dummies & 0.03 & 0.48 & 2.63 & 0.61 & 2.06 & 0.11 \\
\hline Industry Dummies & 0.01 & 0.65 & 0.38 & 0.23 & 1.52 & 0.21 \\
\hline Legal Organization Dummies & 1.48 & 0.49 & 1.3 & 1.78 & 0.82 & 0.14 \\
\hline All Firm Variables Together & 1.76 & 1.69 & 3.94 & 2.67 & 4.28 & 0.5 \\
\hline
\end{tabular}




\begin{tabular}{|c|c|c|c|c|c|c|c|c|c|c|c|c|}
\hline \multirow[b]{2}{*}{ Country Variables } & \multicolumn{6}{|c|}{ Without Former Socialist Economies } & \multicolumn{6}{|c|}{33 Countries } \\
\hline & $\begin{array}{c}\text { Judicial } \\
\text { Efficiency }\end{array}$ & Corruption & $\begin{array}{l}\text { Taxes and } \\
\text { Regulation } \\
\end{array}$ & $\begin{array}{l}\text { Street } \\
\text { Crime }\end{array}$ & $\begin{array}{c}\text { Financing } \\
\text { Obstacle }\end{array}$ & $\begin{array}{c}\text { Firm } \\
\text { Growth }\end{array}$ & $\begin{array}{c}\text { Judicial } \\
\text { Efficiency }\end{array}$ & Corruption & $\begin{array}{r}\text { Taxes and } \\
\text { Regulation } \\
\end{array}$ & $\begin{array}{l}\text { Street } \\
\text { Crime }\end{array}$ & $\begin{array}{c}\text { Financing } \\
\text { Obstacle }\end{array}$ & $\begin{array}{c}\text { Firm } \\
\text { Growth }\end{array}$ \\
\hline Country Dummies & 14.61 & 32.13 & 18.06 & 29.12 & 12.7 & 8.22 & 12.34 & 25.26 & 18.46 & 27.3 & 9.21 & 4.62 \\
\hline Legal Origin Dummies & 5.58 & 4.96 & 3.36 & 5.79 & 1.23 & 1.26 & 3.51 & 0.45 & 4.18 & 4.74 & 0.07 & 1.1 \\
\hline (Rescaled) Legal Formalism & 5.69 & 4.66 & 2.12 & 4.6 & 0.69 & 0.4 & 3.43 & 8.34 & 3.03 & 7.86 & 1.13 & 0.68 \\
\hline Religion Dummies & 3.66 & 6.24 & 2.13 & 4.24 & 1.99 & 0.98 & 2.23 & 2.51 & 3.91 & 1.98 & 0.59 & 0.3 \\
\hline (Rescaled) Ethnic & 1.96 & 5.91 & 2.75 & 2.31 & 1.78 & 0.46 & 0.68 & 4.61 & 4.64 & 4.92 & 0.53 & 0.76 \\
\hline (Rescaled) Settler Mortality & & & & & & & 4.22 & 3.07 & 7.41 & 7 & 1.66 & 0.55 \\
\hline (Rescaled) Latitude & 5.57 & 14.65 & 1.44 & 12.53 & 4.33 & 1.83 & 2.09 & 8 & 2.11 & 8.59 & 1.71 & 0.89 \\
\hline $\begin{array}{l}\text { (Rescaled) Trade } \\
\text { (Rescaled) Checks and }\end{array}$ & 2.27 & 1.82 & 3.66 & 1.73 & 1.04 & 2.2 & 1.26 & 7.9 & 3.22 & 9.01 & 1.56 & 0.77 \\
\hline Balances & 0.91 & 3.62 & 1.05 & 2.14 & 0.46 & 1.4 & 1.04 & 0.05 & 1.87 & 4.08 & 1.62 & 0.61 \\
\hline (Rescaled) Democracy & 6.19 & 8.47 & 1.29 & 8 & 3.07 & 0.4 & 2.37 & 13.78 & 3.62 & 8.39 & 1.73 & 0.26 \\
\hline $\begin{array}{l}\text { (Rescaled) Autocracy } \\
\text { All Institutional Theories }\end{array}$ & 0.38 & 4.33 & 0 & 0.27 & 2.75 & 0.12 & 0.02 & 1.96 & 0.59 & 0.19 & 1.17 & -0.08 \\
\hline Together & 13.97 & 28.32 & 13.84 & 27.24 & 10.43 & 5.96 & 10.76 & 25.26 & 18.46 & 27.3 & 9.21 & 4.62 \\
\hline \multicolumn{13}{|l|}{ Firm Variables } \\
\hline Size Dummies & 0.14 & -0.03 & 0.55 & 0.14 & 1.87 & 0.28 & 0.37 & 0.07 & 0.34 & 0.09 & 2.04 & 0.39 \\
\hline Ownership Dummies & -0.04 & 0.48 & 1.58 & 0.56 & 1.49 & 1.22 & 0.03 & 0.11 & 1.36 & 0.61 & 1.76 & 0.9 \\
\hline Industry Dummies & 0.05 & 0.97 & 0.1 & 0.25 & 0.76 & 0.89 & 0.01 & 0.94 & -0.1 & -0.02 & 0.81 & 0.36 \\
\hline Legal Organization Dummies & 2.35 & 0.76 & 1.69 & 2.5 & 1.91 & 0.93 & 1.48 & 0.91 & 2.81 & 3.16 & 1.72 & 0.83 \\
\hline All Firm Variables Together & 2.56 & 2.23 & 3.15 & 3.5 & 3.9 & 2.57 & 1.76 & 2.05 & 3.76 & 3.75 & 4.03 & 1.84 \\
\hline
\end{tabular}




\section{Table 8: Variance Components}

This table presents the variance components attributed to each of the effects, computed from the Components of Variance Approach. Each cell represents the variance component of the effect in consideration as a percentage of total variance. The variables are defined as follows: Firm Size takes on one of three values for small, medium and large firms, Industrial Sector could be agriculture, manufacturing, services, construction or other, Legal Organization is one of six values to reflect whether the firm is organized as a single proprietorship, partnership, cooperative, privately-held corporation, corporation listed on a stock exchange or another alternative form, and Ownership reflects whether the owner of the firm is an individual, a family, conglomerate group, bank, board of directors, managers, employees, government or other. In each model, the country effect is captured by one of the following variables at the country level: Country Dummies, Legal Origin, Legal Formalism, Religion, Ethnic Fractionalization, Settler Mortality, Latitude, Trade, Checks and Balances, Autocracy and Democracy. Legal Origin takes one of five possible values for the five differen legal traditions: English Common Law, French Civil Law, German Civil Law, Scandinavian Civil Law and Socialist law, Legal Formalism is a measure of procedural formalism in connection with collecting a bounced check, Religion takes one of four different values depending on whether the dominant religious group in the country are Catholics, Protestants, Muslims or Other, Ethnic Fractionalization is the probability that two randomly selected individuals in a country will not speak the same language. Latitude is the absolute value of the latitude of the country scaled between zero and one. Trade is the sum of exports and imports as a fraction of GDP. Checks measures the number of veto-players in the political decision process. Democracy is a measure of the openness of the political system while autocracy is a measure of closedness of the political system. Legal Formalism, Ethnic Fractionalization, Settler Mortality, Latitude, Trade, Checks and Balances, Autocracy and Democracy are rescaled on a five-point scale. The last row in each panel also reports the R-square computed from the variance components. Detailed variable definitions and sources are given in the appendix.

\begin{tabular}{|c|c|c|c|c|c|c|c|c|c|c|}
\hline & \multirow{2}{*}{$\begin{array}{c}\text { I.Benchmark } \\
\\
\text { Country } \\
\text { Dummy } \\
\end{array}$} & \multicolumn{2}{|c|}{ II: Law and Finance } & \multicolumn{2}{|c|}{$\begin{array}{l}\text { III: Culture and Ethnic } \\
\text { Diversity }\end{array}$} & \multirow{2}{*}{$\begin{array}{l}\text { IV: } \\
\text { Endowments } \\
\\
\\
\quad \text { Latitude } \\
\end{array}$} & \multirow{2}{*}{$\begin{array}{l}\begin{array}{l}V: \\
\text { Openness } \\
\text { to Trade }\end{array} \\
\\
\quad \text { Trade } \\
\end{array}$} & \multicolumn{3}{|c|}{ VI: Political View } \\
\hline & & $\begin{array}{c}\text { Legal } \\
\text { Origin } \\
\text { Dummies }\end{array}$ & $\begin{array}{c}\text { Legal } \\
\text { Formalism }\end{array}$ & Religion & Ethnic & & & $\begin{array}{l}\text { Checks and } \\
\text { Balances }\end{array}$ & Democracy & Autocracy \\
\hline \multicolumn{11}{|l|}{ Panel A: } \\
\hline Var (Country) & 15.95 & 5.81 & 0.51 & 1.95 & 1.74 & 4.23 & 2.11 & 3.07 & 5.14 & 2.37 \\
\hline Var (Size) & 0.56 & 0.76 & 2.00 & 1.12 & 1.39 & 0.83 & 1.93 & 1.33 & 1.68 & 1.58 \\
\hline Var (Interactions) & 1.89 & 0.00 & 0.63 & 1.54 & 0.09 & 0.69 & 0.48 & 1.16 & -0.05 & 0.03 \\
\hline$R$-Square & 17.93 & 4.57 & 2.29 & 3.36 & 2.39 & 4.60 & 3.40 & 4.42 & 4.83 & 2.34 \\
\hline \multicolumn{11}{|l|}{ Panel B: } \\
\hline Var (Country) & 16.30 & 5.78 & 0.43 & 2.08 & 1.60 & 4.29 & 2.10 & 3.34 & 5.14 & 2.34 \\
\hline Var (Industry) & -0.02 & -0.03 & 0.15 & -0.18 & 0.06 & -0.10 & 0.10 & 0.01 & 0.22 & 0.18 \\
\hline Var (Interactions) & 1.32 & 0.22 & 0.92 & 1.26 & 0.57 & 0.63 & 0.69 & 0.50 & 0.04 & 0.19 \\
\hline$R$-Square & 17.30 & 4.21 & 1.30 & 2.34 & 1.86 & 3.99 & 2.39 & 3.15 & 3.94 & 1.54 \\
\hline \multicolumn{11}{|l|}{ Panel C: } \\
\hline Var (Country) & 15.93 & 5.68 & 0.55 & 2.16 & 1.25 & 4.19 & 1.93 & 3.31 & 4.88 & 2.27 \\
\hline Var (Organization) & 0.45 & -0.05 & 1.33 & 0.56 & 0.41 & 0.15 & 0.84 & 1.04 & 0.64 & 0.54 \\
\hline Var (Interactions) & 2.13 & 0.77 & 0.60 & 1.43 & 2.24 & 1.37 & 1.69 & 0.74 & 1.18 & 0.56 \\
\hline$R$-Square & 18.13 & 4.63 & 2.06 & 3.19 & 3.47 & 4.83 & 3.82 & 4.20 & 5.22 & 2.18 \\
\hline \multicolumn{11}{|l|}{ Pane D: } \\
\hline Var (Country) & 16.42 & 5.50 & 0.34 & 1.72 & 1.14 & 4.24 & 1.90 & 3.19 & 5.04 & 2.39 \\
\hline Var (Ownership) & 0.35 & 0.42 & 1.84 & 0.82 & 1.31 & 1.24 & 1.69 & 1.35 & 1.78 & 2.09 \\
\hline Var (Interactions) & 1.10 & 1.22 & 1.62 & 3.11 & 2.45 & 0.84 & 1.64 & 1.22 & 0.28 & -0.10 \\
\hline$R$-Square & 17.50 & 5.30 & 3.22 & 4.62 & 4.25 & 5.19 & 4.38 & 4.75 & 5.33 & 2.82 \\
\hline
\end{tabular}




\section{Table 9: Determinants of Firms' Perception of Property Rights Protection -Non Linear Estimation}

This table documents the contribution of each effect to the McKelvey and Zavoina(1975) R-square of the logistic regression model. The regression model in Panel A(B)(C)(D) is Property Rights $_{i j}=$ Country Effect $_{i}+$ Firm Size $_{j}$ (or Industry Sector $\left.{ }_{j}\right)\left(\right.$ or Legal Organization $\left._{j}\right)\left(\right.$ or Ownership $\left._{\mathrm{j}}\right)+$ Country Effect $_{\mathrm{i}}$ * Firm Size $_{\mathrm{j}}\left(\right.$ or Industry Sector $\left._{\mathrm{j}}\right)\left(\right.$ or Legal Organization $\left._{\mathrm{j}}\right)\left(\right.$ or Ownership $\left._{\mathrm{j}}\right)$. Firm Size takes on one of three values for small, medium and large firms, Industrial Sector could be agriculture, manufacturing, services, construction or other, Legal Organization is one of six values to reflect whether the firm is organized as a single proprietorship, partnership, cooperative, privately-held corporation, corporation listed on a stock exchange or another alternative form, and Ownership reflects whether the owner of the firm is an individual, a family, conglomerate group, bank, board of directors, managers, employees, government or other. In each regression, the country effect is captured by one of the following variables at the country level: Country Dummies, Legal Origin, Legal Formalism, Religion, Ethnic Fractionalization, Latitude, Trade, Checks and Balances, Autocracy and Democracy. The variables are defined as follows: Legal Origin takes one of five possible values for the five different legal traditions: English Common Law, French Civil Law, German Civil Law, Scandinavian Civil Law and Socialist law, Legal Formalism is a measure of procedural formalism in connection with collecting a bounced check, Religion takes one of four different values depending on whether the dominant religious group in the country are Catholics, Protestants, Muslims or Other, Ethnic Fractionalization is the probability that two randomly selected individuals in a country will not speak the same language. Latitude is the absolute value of the latitude of the country scaled between zero and one. Trade is the sum of exports and imports as a fraction of GDP. Checks measures the number of veto-players in the political decision process. Democracy is a measure of the openness of the political system while autocracy is a measure of closedness of the political system. Legal Formalism, Ethnic Fractionalization, Latitude, Trade, Checks and Balances, Autocracy and Democracy are rescaled on a five point scale. Dummy variables are used for the all the country and firm variables. Detailed variable definitions and sources are given in the appendix.

\begin{tabular}{|c|c|c|c|c|c|c|c|c|c|c|c|}
\hline & \multirow{2}{*}{$\begin{array}{l}\begin{array}{l}\text { I: } \\
\text { Benchmark }\end{array} \\
\text { Country } \\
\text { Dummy }\end{array}$} & \multicolumn{2}{|c|}{$\begin{array}{l}\text { II: Law and Finance } \\
\text { View }\end{array}$} & \multicolumn{2}{|c|}{$\begin{array}{l}\text { III: Culture-Ethnic } \\
\text { Diversity }\end{array}$} & \multirow{2}{*}{$\begin{array}{l}\text { IV: } \\
\text { Endowments } \\
\\
\quad \text { Latitude }\end{array}$} & \multirow{2}{*}{$\begin{array}{l}\begin{array}{l}\text { V: } \\
\text { Openness } \\
\text { to Trade }\end{array} \\
\\
\quad \text { Trade } \\
\end{array}$} & \multicolumn{3}{|c|}{ VI: Political View } & \multirow[t]{2}{*}{$\begin{array}{l}\text { VII: All Institutional } \\
\text { Theories Together }\end{array}$} \\
\hline & & $\begin{array}{c}\text { Legal } \\
\text { Origin } \\
\text { Dummies }\end{array}$ & $\begin{array}{c}\text { Legal } \\
\text { Formalism }\end{array}$ & Religion & Ethnic & & & $\begin{array}{c}\text { Checks } \\
\text { and } \\
\text { Balances }\end{array}$ & Democracy & Autocracy & \\
\hline \multicolumn{12}{|l|}{ Panel A: } \\
\hline Country & 17.7 & 4.4 & 0.6 & 1.7 & 1.5 & 3.8 & 1.9 & 2.8 & 3.6 & 1.3 & 13.2 \\
\hline Size & 0.3 & 0.5 & 1.5 & 1.1 & 0.9 & 0.6 & 1.3 & 1.1 & 1.2 & 1 & 0.6 \\
\hline Interactions & 2.9 & 0.2 & 0.5 & 0.9 & 0.3 & 0.5 & 0.3 & 0.8 & 0 & 0.1 & 2 \\
\hline \multicolumn{12}{|l|}{ Panel B: } \\
\hline Industrial Sector & 0 & 0.1 & 0.4 & 0.3 & 0.2 & 0.1 & 0.2 & 0.2 & 0.3 & 0.2 & 0.1 \\
\hline Interactions & . & 0.3 & 0.7 & 0.8 & . & 0.7 & 0.6 & 0.5 & 0.2 & 0.2 & . \\
\hline Total & 17.7 & 4.8 & 1.7 & 2.8 & & 4.6 & 2.7 & 3.5 & 4.1 & 1.7 & \\
\hline \multicolumn{12}{|l|}{ Panel C: } \\
\hline Country & 17.7 & 4.4 & 0.6 & 1.7 & 1.5 & 3.8 & 1.9 & 2.8 & 3.6 & 1.3 & 13.2 \\
\hline Legal Organization & 0.4 & 0.3 & 1.2 & 0.9 & 0.8 & 0.4 & 1 & 1.1 & 0.9 & 0.7 & 0.7 \\
\hline \multicolumn{12}{|l|}{ Panel D: } \\
\hline Ownership & 0.3 & 0.9 & $\begin{array}{l}0.0 \\
1.9\end{array}$ & 1.7 & 1.6 & 1.3 & 1.7 & $\begin{array}{l}2.0 \\
1.5\end{array}$ & $\begin{array}{l}5.0 \\
1.6\end{array}$ & 1.7 & 0.7 \\
\hline Interactions & . & 1 & . & 2.1 & 2 & 1 & 1.5 & . & 0.5 & 0.2 & . \\
\hline Total & 18 & 6.3 & & 5.5 & 5.1 & 6.1 & 5.1 & & 5.7 & 3.2 & \\
\hline
\end{tabular}


Appendix A1: Comparison of Different Theories of Property Rights

\begin{tabular}{|c|c|c|c|c|}
\hline Theory & Variables & $\begin{array}{l}\text { Country-Level } \\
\text { Implications }\end{array}$ & $\begin{array}{l}\text { Firm-Level Implications (Following } \\
\text { have better property rights protection) }\end{array}$ & Related Papers \\
\hline $\begin{array}{l}\text { Law and Finance } \\
\text { View }\end{array}$ & Legal Origin & $\begin{array}{l}\text { Common Law countries } \\
\text { protect property rights better } \\
\text { than Civil law countries }\end{array}$ & $\begin{array}{l}\text { Size: Larger firms in Civil law countries } \\
\text { Ownership: Bank Owned firms in } \\
\text { German civil law countries, Groups in } \\
\text { poor legal protection countries } \\
\text { Legal Status: Corporations in common } \\
\text { law countries and Incorporated firms in } \\
\text { countries with weak bankruptcy laws. } \\
\text { Industry: }\end{array}$ & $\begin{array}{l}\text { LLSV (1998); Fisman and Khanna } \\
\text { (2004); Laeven and Woodruff (2004), } \\
\text { Kumar, Rajan and Zingales (2002) }\end{array}$ \\
\hline
\end{tabular}

Size: None

Ownership: None

Legal Status: None

Countries closer to the Industry: Settlers were protective of

equator and colonies with certain industries like mining and

Latitude, Settler high settler mortality have

Endowment View Mortality more extractive systems

extraction, railroad construction among

others.

AJR (2001)

\section{Size: None}

\section{Ownership: None}

Legal Status: Corporations in common

Countries scoring higher on law countries and Incorporated firms in

Formalism the formalism index protect

countries with weak bankruptcy laws.

Djankov et. al (2003), Acemoglu property rights better.

Industry: None

(2003), Glaeser and Shleifer (2002), Johnson et. al. (2000) 


\begin{tabular}{|c|c|c|c|c|}
\hline Theory & Variables & $\begin{array}{l}\text { Country-Level } \\
\text { Implications }\end{array}$ & $\begin{array}{l}\text { Firm-Level Implications (Following } \\
\text { have better property rights protection) }\end{array}$ & Related Papers \\
\hline $\begin{array}{l}\text { Culture and Ethnic } \\
\text { Diversity View }\end{array}$ & $\begin{array}{l}\text { Religion, Ethnic } \\
\text { Fractionalization }\end{array}$ & $\begin{array}{l}\text { Countries that are ethnically } \\
\text { more homogeneous and } \\
\text { Christian countries and have } \\
\text { better enforcement of } \\
\text { property rights (and stronger } \\
\text { for Protestant than Catholic } \\
\text { countries). }\end{array}$ & $\begin{array}{l}\text { Size: None } \\
\text { Ownership: Family or group owned firms } \\
\text { when they belong to a particular } \\
\text { religious/ethnic group } \\
\text { Legal Status: } \\
\text { Industry: }\end{array}$ & $\begin{array}{l}\text { LLSV (1999), Stulz (2002), Easterly } \\
\text { and Levine (1997), Stulz and } \\
\text { Williamson (2003) }\end{array}$ \\
\hline Political View & $\begin{array}{l}\text { Democracy, } \\
\text { Autocracy, } \\
\text { Checks and } \\
\text { Balances }\end{array}$ & $\begin{array}{l}\text { Property Rights are better } \\
\text { protected in a more } \\
\text { democratic and open country }\end{array}$ & $\begin{array}{l}\text { Size: Large incumbent firms in oligarchy } \\
\text { have better property rights } \\
\text { Ownership: Government owned firms in } \\
\text { less democratic countries } \\
\text { Legal Status: Sole proprietorships have } \\
\text { poor protection in less democratic } \\
\text { countries } \\
\text { Industry: Agriculture gets better property } \\
\text { rights protection because many agro- } \\
\text { based economies are non democratic and } \\
\text { people in power don't want to upset the } \\
\text { farmers }\end{array}$ & Acemoglu (2003) \\
\hline
\end{tabular}

\begin{tabular}{|c|c|c|c|c|}
\hline Openness View & Trade & $\begin{array}{l}\text { Property Rights are better } \\
\text { protected in countries open } \\
\text { to international trade }\end{array}$ & $\begin{array}{l}\text { Size: } \text { Large firms } \\
\text { Ownership: } \\
\text { Legal Status: } \\
\text { Industry: Manufacturing typically has } \\
\text { higher property rights protection in } \\
\text { countries not open to trade because it's } \\
\text { the backbone of the economy }\end{array}$ & Rajan and Zingales (2000) \\
\hline
\end{tabular}




\section{Appendix A2: Variable Definitions}

\begin{tabular}{|c|c|c|}
\hline Variable & Variable Definitions & Source \\
\hline \multicolumn{3}{|l|}{ Dependent Variables } \\
\hline Property Rights & $\begin{array}{l}\text { Scored 1-6, it is an indicator of firm responses to the survey question "I am confident that the judicial system } \\
\text { will enforce my contractual and property rights in business disputes". } 1 \text { denotes the highest level of confidence } \\
\text { and } 6 \text { denotes the poorest }\end{array}$ & World Business Environment Survey \\
\hline Judicial Efficiency & $\begin{array}{l}\text { Scored } 1-4, \text { it is an indicator of firm responses to the survey question "How problematic is judicial efficiency } \\
\text { for the operation and growth of your business: no obstacle (1), a minor obstacle (2), a moderate obstacle (3) or } \\
\text { a major obstacle (4)?" }\end{array}$ & World Business Environment Survey \\
\hline Crime & $\begin{array}{l}\text { Scored 1-4, it is an indicator of firm responses to the survey question "How problematic is street crime for the } \\
\text { operation and growth of your business: no obstacle (1), a minor obstacle (2), a moderate obstacle (3) or a } \\
\text { major obstacle (4)?" }\end{array}$ & World Business Environment Survey \\
\hline Corruption & $\begin{array}{l}\text { Scored } 1-4, \text { it is an indicator of firm responses to the survey question "How problematic is corruption for the } \\
\text { operation and growth of your business: no obstacle (1), a minor obstacle (2), a moderate obstacle (3) or a } \\
\text { major obstacle (4)?" }\end{array}$ & World Business Environment Survey \\
\hline Financing & $\begin{array}{l}\text { Scored 1-4, it is an indicator of firm responses to the survey question "How problematic is financing for the } \\
\text { operation and growth of your business: no obstacle (1), a minor obstacle (2), a moderate obstacle (3) or a } \\
\text { major obstacle (4)?" }\end{array}$ & World Business Environment Survey \\
\hline Taxes and Regulation & $\begin{array}{l}\text { Scored } 1-4 \text {, it is an indicator of firm responses to the survey question "How problematic are taxes and } \\
\text { regulation for the operation and growth of your business: no obstacle (1), a minor obstacle (2), a moderate } \\
\text { obstacle (3) or a major obstacle (4)?" }\end{array}$ & World Business Environment Survey \\
\hline Firm Growth & Estimate of the firm's sales growth over the past three years & World Business Environment Survey \\
\hline \multicolumn{3}{|l|}{ Firm Variables } \\
\hline Firm Size Dummies & $\begin{array}{l}\text { A firm is defined as small if it has between } 5 \text { and } 50 \text { employees, medium size if it has between } 51 \text { and } 500 \\
\text { employees and large if it has more than } 500 \text { employees. }\end{array}$ & World Business Environment Survey \\
\hline Ownership Dummies & $\begin{array}{l}\text { Indicates identity of the owner. Nine different categories are identified: Individual, Family, Conglomerate } \\
\text { group, Bank, Board of directors, Managers, Employees, Government, and Others }\end{array}$ & World Business Environment Survey \\
\hline Industry Dummies & $\begin{array}{l}\text { Indicates industrial sector in which the firm operates. Five different categories: Manufacturing, Agriculture, } \\
\text { Services, Construction, and Other }\end{array}$ & World Business Environment Survey \\
\hline Legal Organization Dummies & $\begin{array}{l}\text { Indicates legal status of the company, whether it is organized as a single proprietorship, partnership, } \\
\text { cooperative, privately-held corporation, corporation listed on a stock exchange and a other category }\end{array}$ & World Business Environment Survey \\
\hline
\end{tabular}




\section{Institutional Variables}

Legal Origin

An indicator of the type of legal system in the country. It takes the value 1 for English Common law, 2 for French Civil Law, 3 for German Civil Law, 4 for Scandinavian Civil Law and 5 for Socialist Law countries

The index measures substantive and procedural statutory intervention in judicial cases at lower-level civil tria courts, and is formed by adding up the following indices: (i) professionals vs. laymen, (ii) written vs. oral elements, (iii) legal justification, (iv) statutory regulation of evidence, (v) control of superior review, (vi) engagement formalities, and (vii) independent procedural actions. The index ranges from 0 to 7 , where 7 means a higher level of control or intervention in the judicial process

Religion

Ethnic Fractionalization

Settler Mortality

Latitude

Trade

Checks

Democracy

An indicator of the dominant religious group in the country. It takes the value 1 for Catholics, 2 for Protestants, 3 for Muslims, and 4 for Others

Probability that two randomly selected individuals in a country will not speak the same language

Log of the annualized deaths per thousand European soldiers in European colonies in the early 19th century

Absolute value of the latitude of a country, scaled between zero and one

Share of Imports plus Exports in GDP

Measure of the number of veto-players in the political decision process, both in the executive and the legislature. Average for 1990-95

An indicator of the general openness of political institutions, scored from 0 (low) to 10 (high). The 11-point scale is an additive weighted indicator of the following political variables(weights used are indicated in brackets): Competitiveness of Executive Recruitment (Election (+2), Transitional (+1)), Openness of

Executive Recruitment (Dual/Election $(+1)$, Election $(+1)$ ), Constraint on Chief Executive (Executive party or subordination (+4), Intermediate category $(+3)$, Substantial limitations $(+2)$, Intermediate category $(+2))$ and the Competitiveness of Political Participation (Competitive (+3), Transitional (+2), Factional (+1)). Detaile descriptions of the sub-components of the democracy indicator is available from the Polity IV manual. An indicator of the general closedness of political institutions, scored from 0 (low) to 10 (high). The 11-point An indicator of the general closedness of political institutions, scored from 0 (low) to 10 (high). The $11-p o i r$
scale is an additive weighted indicator of the following political variables (weights used are indicated in brackets): Competitiveness of Executive Recruitment (Selection (+2)), Openness of Executive Recruitmen

Autocracy
$($ Closed (+1), Dual/designation (+1)), Constraint on Chief Executive (Unlimited authority $(+3)$, Intermediate category (+2), Slight to moderate limitations $(+1)$, Regulation of Political Participation (Restricted $(+2)$,

Sectarian $(+1)$ and the Competitiveness of Political Participation (Repressed (+2), Suppressed $(+1))$. Detailed descriptions of the sub-components of the autocracy indicator is available from the Polity IV manual.
La Porta, Lopez-de-Silanes, Shleifer and Vishny (1999)

Djankov, La Porta, Lopez-de-Silanes, and Shleifer (2003)

La Porta, Lopez-de-Silanes, Shleifer and Vishny (1999)

Easterly and Levine (1997)

Acemoglu, Johnson, and Robinson (2001)

La Porta, Lopez-de-Silanes, Shleifer and Vishny (1999)

World Development Indicators Beck, Clark, Groff, Keefer, and Walsh (2001)

Polity IV Dataset 


\section{Appendix A3: Effect of Rescaling Commonly Used Proxies for Institutional Theories}

We identify significant non-linearities in the construction of commonly used proxies used to represent the institutional theories, that questions their use in linear models. We illustrate our point below with the democracy and checks variables that are used to represent the political view. The political view predicts that greater democracy and more checks and balances will limit the ability of the elite to dictate policy and institutional development and hence results in better property rights protection. Figures $3 \mathrm{a}$ and $3 \mathrm{~b}$ plot the regression coefficients from the regression of firm's responses to the property rights question on a set of dummies for different values of the Democracy and Checks variables respectively. The figures show significant non-linearities in the relation between property rights protection and democracy (or checks). This is also seen in the adjusted R-squares. Regression of property rights on Democracy (Checks) gives an adjusted R-square of $0.68 \%(0 \%)$, on Democracy(Checks) and its square increases the R-square to $2.50 \%(1.41 \%)$ and when we also include the cube of Democracy, the adjusted R-square jumps to $3.43 \%(1.6 \%$ in the case of Checks). Corresponding analysis for the other variables (ethnic, latitude, formalism, trade, and autocracy) reveals again the presence of non-linearities, which puts the theories they represent at a statistical disadvantage in a linear model when compared to religion and legal origin.

Figure 3a: Regression of property rights on Democracy Scores

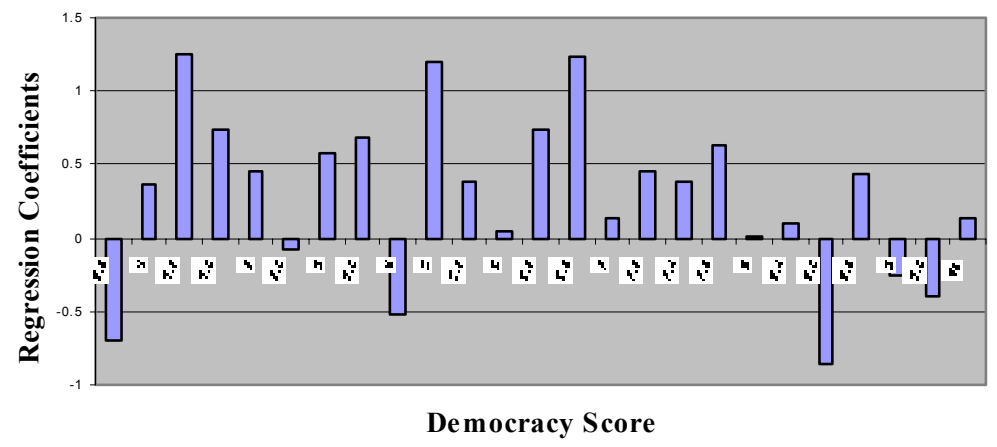

Figure 3b: Regression of property rights on Checks

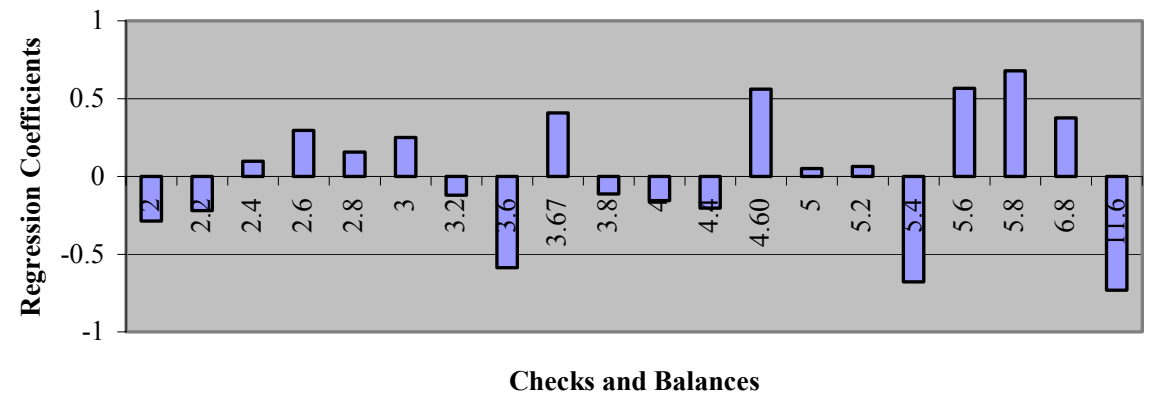


To even the playing field, first we construct a five point scale for all the variables, based on their quantiles $^{38}$, to ensure the same number of categories as legal origin. Figure $3 \mathrm{~b}$ plots the new regression coefficients when we regress property rights on dummies created by the newly scaled Democracy variable. The figure shows a monotonic relation between property rights and democracy, justifying inclusion in a linear model framework --more democratic the political framework in the country, firms are more confident of their property rights being protected and code the variable lower. Figure $4 \mathrm{~b}$ shows that re-scaling the Checks variable does reduce the non-linearities to a large extent but not enough to make it monotonic. Since the checks and balances variable has been used repeatedly to capture the Political view of property rights, we retain it in our linear analysis while acknowledging that any results from using the variable in a linear model framework are bound to be biased.

Figure 4a: Regression of property rights on Rescaled-

Democracy Scores

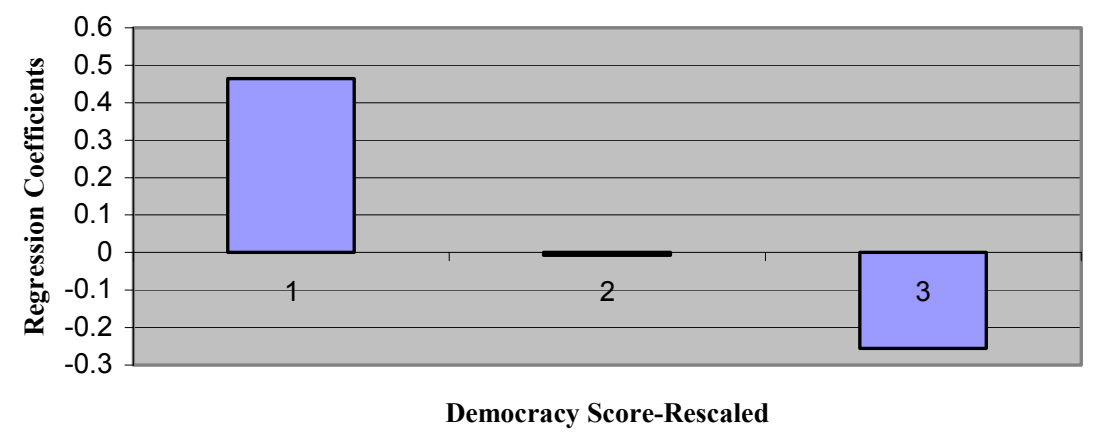

Figure 4b: Regression of property rights on Rescaled Checks

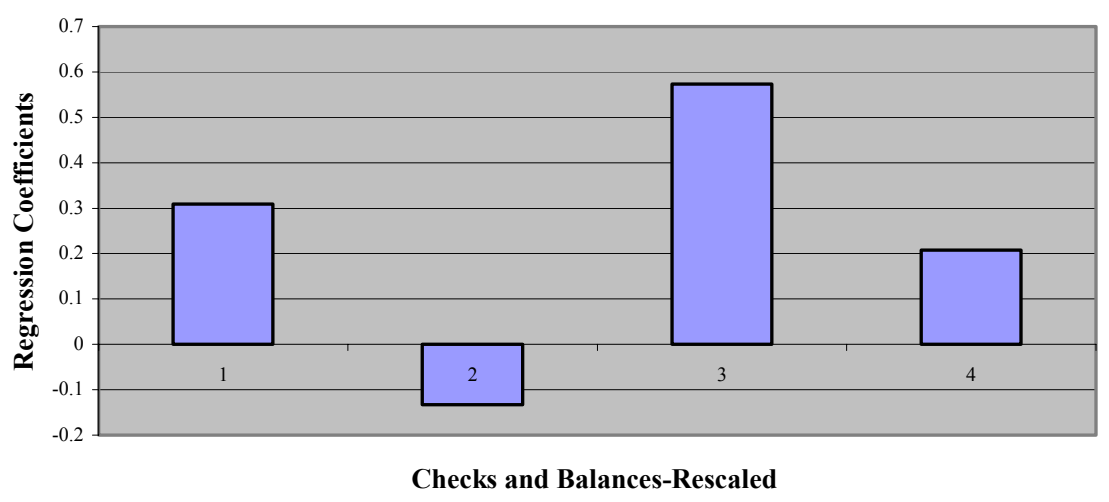

${ }^{38}$ Since the variables are rescaled on a five point scale on the basis of quantiles and dummies are used in the regresions, four regression coefficients are obtained for each variable. However, inadequate variation in democracy and autocracy scores produces regression coefficients for only three quantiles. Hence the rescaled democracy variable has regression coefficients reported for only three quantiles. 